\title{
Geochemistry of Lavas from Mauritius, Indian Ocean: Mantle Sources and Petrogenesis
}

\author{
H. C. SHETh, ${ }^{1}$ J. J. MAHONEY, \\ Department of Geology and Geophysics, School of Ocean and Earth Science and Technology (SOEST), \\ University of Hawaii at Manoa, Honolulu, Hawaii 96822 \\ AND A. N. BAXTER \\ School of Earth and Environmental Sciences, University of Greenwich, Chatham Maritime, Kent, ME4 4TB United Kingdom
}

\begin{abstract}
Trace-element and Nd-Sr-Pb isotopic data for mafic lavas from the Mascarene island of Mauritius reveal that the shield-stage Older Series (with ${ }^{143} \mathrm{Nd} /{ }^{144} \mathrm{Nd}=0.512827$ to $0.512853,{ }^{87} \mathrm{Sr} /{ }^{86} \mathrm{Sr}=$ 0.70412 to 0.70433 , and ${ }^{206} \mathrm{~Pb} /{ }^{204} \mathrm{~Pb}=18.771$ to 19.024 ) is geochemically very similar to the shield-building lavas of the younger island of Réunion. The post-shield Intermediate and Younger Series lavas of Mauritius have systematically greater values of ${ }^{143} \mathrm{Nd} /{ }^{144} \mathrm{Nd}$ and lower ${ }^{87} \mathrm{Sr} /{ }^{86} \mathrm{Sr}$ ratios than the Older Series and Réunion lavas. Intermediate and Younger Series Nd and Sr isotopic ratios are closely similar $(0.512874$ to $0.512899 ; 0.70369$ to 0.70401$)$, whereas ${ }^{206} \mathrm{~Pb} / 204 \mathrm{~Pb}$ ranges from values as great as any for the Older Series and Réunion lavas to as low as 18.608. Most of the Intermediate Series lavas are strongly enriched in highly incompatible elements relative to moderately incompatible ones (e.g., chondrite-normalized $\mathrm{La} / \mathrm{Lu}=4.03-17.8$ vs. 9.38-10.2 for the Older Series), but the Younger Series lavas display much less relative enrichment (e.g., chondrite-normalized $\mathrm{La} / \mathrm{Lu}=3.86-5.37$ ) and have low concentrations of incompatible elements. Modeling suggests that variable partial melting and mixing between mid-ocean-ridge-basalt (MORB) source mantle and mantle with bulk-Earth-like Nd and Sr isotopic and incompatible-element ratios, and "C"-like $\mathrm{Pb}$ isotope ratios, can explain the general relationship between the shield and post-shield lavas. All Mauritius and Réunion lavas can be explained as 2-8\% partial melts of a bulk-Earth-like source that had been $1.5-0.25 \%$ metasomatized by a $0.1 \%$ MORB-source melt. The range in $\mathrm{Pb}$ isotopic compositions requires mixing with highly variable $\mathrm{Sr} / \mathrm{Pb}$ and $\mathrm{Nd} / \mathrm{Pb}$ ratios in the end members; such variation, however, is not supported by measured $\mathrm{Sr} / \mathrm{Pb}, \mathrm{Nd} / \mathrm{Pb}$, etc. in the lavas. Some isotopic heterogeneity thus appears to be required in the end members and/or much of the range in $\mathrm{Pb}$ isotopes represents radiogenic ingrowth since the metasomatic event. Near-constant ${ }^{207} \mathrm{~Pb} /{ }^{204} \mathrm{~Pb}$ values over the range of ${ }^{206} \mathrm{~Pb} /{ }^{204} \mathrm{~Pb}$ among the Older Series lavas suggest that the metasomatic event must have occurred within the last few hundred million years.
\end{abstract}

\section{Introduction}

THE INDIAN OCEAN BASIN has a complex geology, with four major branches of the worldwide oceanic ridge system (the Southeast Indian, Southwest Indian, Central Indian, and Carlsberg ridges), numerous large fracture zones, and several volcanic island/seamount chains (Fig. 1). The island of Mauritius $\left(20^{\circ} 20^{\prime} \mathrm{S}, 57^{\circ} 30^{\prime} \mathrm{E}\right)$ lies at the southern end of the Mascarene Plateau, a major volcanic edifice that extends northward to the Seychelles Islands (e.g.,

\footnotetext{
${ }^{1}$ Corresponding author; email: hesheth@iitb.ac.in. Now at Department of Earth Sciences, Indian Institute of Technology (IIT), Powai, Bombay 400076 India.
}

Fisher et al., 1967, 1971; Baxter, 1975a, 1975b). The islands of Mauritius, Rodrigues $(650 \mathrm{~km}$ ENE of Mauritius), and Réunion (170 km WSW of Mauritius) together constitute the Mascarene Islands.

Volcanic activity on Rodrigues ceased $\sim 1.5 \mathrm{Ma}$ (million years ago), and that on Mauritius at $0.17 \mathrm{Ma}$ (McDougall and Chamalaun, 1969), whereas Réunion Island is still volcanically active. Morgan (e.g., 1981) proposed that the Réunion "hotspot" was the manifestation of a deep mantle plume, and that the track of this plume on the northward-moving Indian plate is represented by Réunion, Mauritius, and the Mascarene Plateau, the LaccadivesMaldives-Chagos Ridge, and the Deccan flood basalt province of India (Fig. 1). Morgan (1981) also specu- 


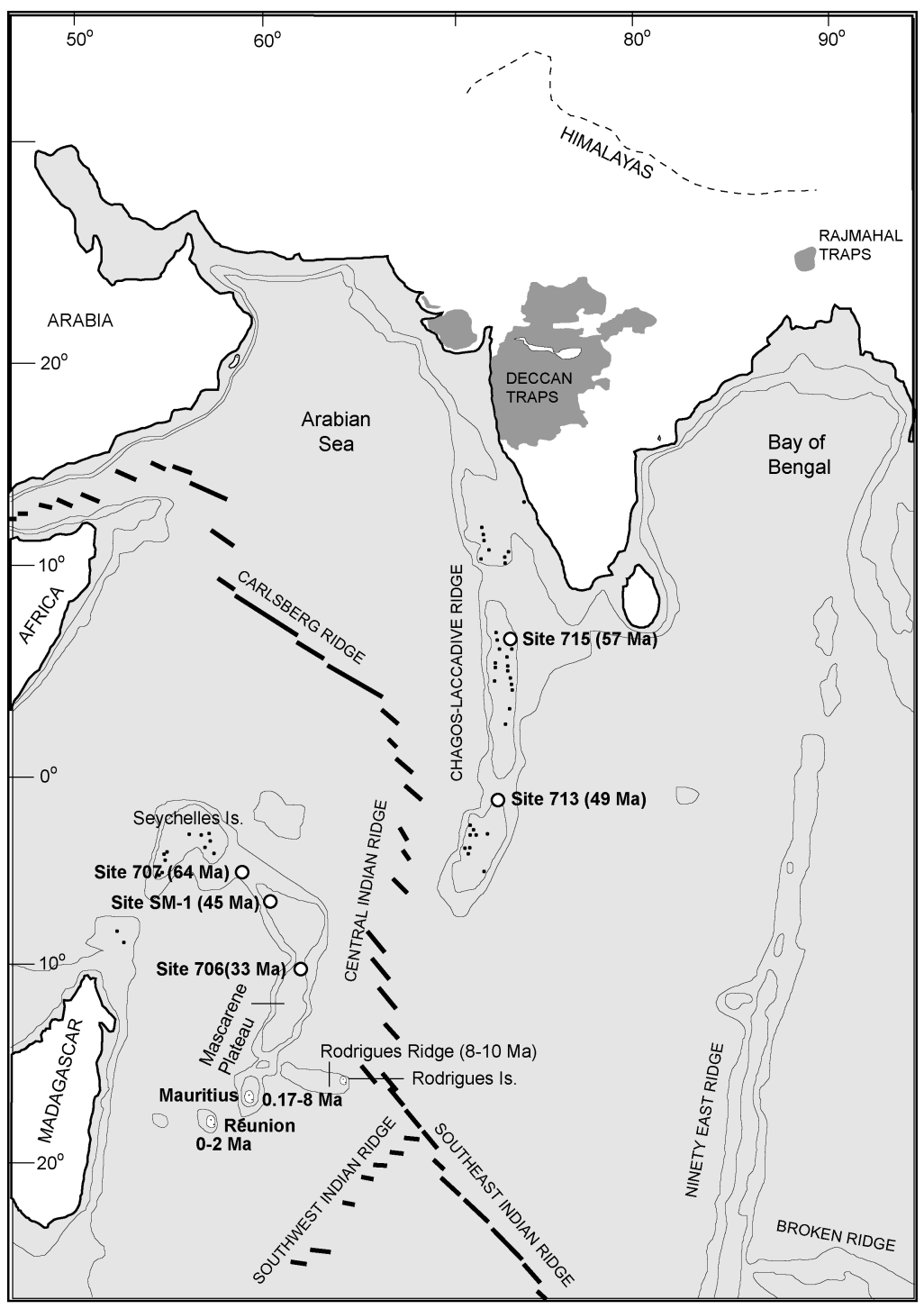

FIG. 1. Map of southern Asia and the Indian Ocean basin, showing the main tectonic and physiographic features of the latter. Based on maps of Mahoney et al. (2002) and Duncan (1990). ODP Leg 115 sites (706, 107, 713, 715) and Texaco drill site SM-1 are indicated by open circles; the ages of the basalts are from McDougall and Chamalaun (1969) and Duncan and Hargraves (1990).

lated that the E-W-trending Rodrigues Ridge formed by lateral flow of Réunion hotspot mantle toward the Central Indian Ridge (CIR), as the CIR gradually migrated away from the hotspot. The Rodrigues Ridge does not extend all the way to the CIR, however, and appears to lack an age progression (Duncan, 1990); Rodrigues Island lies at its eastern terminus.
Réunion Island rises $7 \mathrm{~km}$ from an ocean floor of Paleocene age and consists of two shield volcanoes. Piton de La Fournaise $(2,361 \mathrm{~m})$ is active, and one of the most productive in the world. The other, Piton des Neiges (3,069 m), lies $30 \mathrm{~km}$ northwest of Piton de la Fournaise, and is now extinct (Bachèlery et al., 1982; Fisk et al., 1988). Lavas from both volcanoes 
have been studied extensively (e.g., McDougall, 1971; Fisk et al., 1988; Albarède and Tamagnan, 1988; Gillot and Nativel, 1989; Staudacher et al., 1990; White et al., 1990; Albarède et al., 1997; Hanyu et al., 2001). In comparison, few studies of Rodrigues Island lavas exist (e.g., McDougall et al, 1965; Baxter et al., 1985). For Mauritius, K-Ar (McDougall and Chamalaun, 1969), petrographic, major-element and some trace-element data (Baxter, 1972; 1975a, 1975b, 1976) are available, along with a small number of isotopic data. The latter include $\mathrm{Nd}$ and Sr isotopic data for eight samples (Mahoney et al., 1989), and $\mathrm{Pb}$ isotopic data for two of these samples (Peng and Mahoney, 1995). Noble gas isotope data for a few Mauritius lavas and for a larger number of Réunion lavas were recently published by Hanyu et al. (2001). In this paper, we present major-element, detailed trace element, and $\mathrm{Nd}-\mathrm{Sr}-$ $\mathrm{Pb}$ isotopic data for a suite of Mauritius lavas, and discuss the implications for the mantle sources and petrogenetic evolution of these lavas.

\section{General Volcanic Geology of Mauritius}

Baxter (1972) recognized three distinct volcanic series on Mauritius: the Older, Intermediate, and Younger Series. The Older Series, marking the erosional remnants of a large shield volcano, is a variably differentiated transitional basalt to trachyte suite (Baxter, 1975a). It is composed of two stages. The first, a shield-building stage, consists of an alternating lava-agglomerate succession with flows of olivine basalt, with minor feldspar-phyric basalt and trachybasalt toward the top of the succession; the porphyritic mafic lavas host ultramafic nodules. A radial dike swarm is associated with this stage. The second stage forms a late-shield sequence of feldspar-phyric basalt and trachybasalt, with associated trachytic intrusions. The post-shield Intermediate Series lavas are restricted to the southwestern part of the island, and predominantly comprise alkali-olivine basalt, basanite, and subordinate nephelinite. The volume of the Intermediate Series is small compared to the volumes of the Older and the Younger Series. Younger Series lavas cover the bulk of the island, and are mostly olivine basalts with smaller volumes of basanite. They were probably erupted as the terminal stages of major fissure eruptions from a group of small volcanoes aligned ENE-WSW. K-Ar dating by McDougall and Chamalaun (1969) yielded ages of 7.8-5.5 Ma for the Older Series, 3.5-1.9 Ma for the Intermediate Series, and 0.70-0.17 Ma for the Younger Series.
The evolution of Mauritius is rather similar to that of many ocean islands worldwide, including the Hawaiian islands. Hawaiian volcanoes typically evolve through four distinct eruptive stages (e.g., Stearns, 1940; Macdonald and Katsura, 1964; Macdonald, 1968; Clague, 1987). The first is a pre-shield stage, consisting of alkalic and some tholeiitic lavas, followed by a tholeiitic shield-building stage that constitutes $\sim 99 \%$ of a volcano's volume. This is followed by a post-shield alkalic stage, and often, several million years later, a post-erosional or rejuvenated alkalic stage. The pre-shield stage has been observed only for the youngest volcano in the Hawaiian chain, Loihi, and is inferred for the other Hawaiian volcanoes whose inaccessible foundations lie several kilometers underneath their exposed tops.

Using the major elements and several trace elements, Baxter (1975a) inferred an important role for fractionation of olivine + clinopyroxene ( \pm plagioclase \pm titanomagnetite) in the evolution of the Mauritius Older Series basalts, and the fractionation of anorthoclase in the evolution of the trachytes. He tentatively ascribed a distinct "silica gap" within the series to secondary boiling. Baxter (1976) argued that incompatible-element enrichment patterns in alkali basalts from the Intermediate and Younger Series, and their highly variable $\mathrm{Rb} / \mathrm{Sr}, \mathrm{K} /$ $\mathrm{Rb}, \mathrm{K} / \mathrm{Sr}$, and $\mathrm{K} / \mathrm{Ba}$ ratios, suggested formation by low-degree, possibly sequential melting of a single peridotitic mantle source. He suggested that the relatively low incompatible-element concentrations in the Younger Series either reflected higher degrees of partial melting, or the melting of mantle already depleted in incompatible elements during production of the Intermediate Series magmas.

\section{Samples and Analytical Methods}

The samples used in this study are from Baxter's collection, and all are from lava flows. Major element oxides (except $\mathrm{Na}_{2} \mathrm{O}$ ) and several trace elements in a large number of tungsten-carbide-ground powders were analyzed by Baxter (1972) using Xray fluorescence spectrometry (XRFS); $\mathrm{Na}_{2} \mathrm{O}$ was analyzed by flame photometry. We analyzed fourteen of these samples for a larger suite of trace elements, including the lanthanide rare-earth elements (REE), at the University of Hawaii by inductively coupled plasma mass spectrometry (ICPMS), following the method of Jain and Neal (1996). Major- and traceelement compositions are reported in Table 1. Nine of the samples (three from each series) were also analyzed for $\mathrm{Nd}, \mathrm{Sr}$, and $\mathrm{Pb}$ isotopic ratios, and $\mathrm{Pb}$ 
TABLE 1. Major- and Trace-Element Compositions of Mauritius Lavas ${ }^{1}$

\begin{tabular}{|c|c|c|c|c|c|c|c|c|c|c|c|c|c|c|c|c|}
\hline Series: & OS & OS & OS & IS & IS & IS & IS & IS & IS & YS & YS & YS & YS & YS & Recomm. & Meas. \\
\hline Type: & $\mathrm{SAB}$ & SAB & $A B$ & $A B$ & BAS & $\mathrm{AB}$ & $\mathrm{AB}$ & BAS & BAS & $\mathrm{AB}$ & $\mathrm{AB}$ & $\mathrm{AB}$ & $\mathrm{SAB}$ & $\mathrm{AB}$ & & \\
\hline Sample: & A168 & A169 & A 215 & $\mathrm{Bl}$ & B5 & B18 & B19 & B33 & B34 & $\mathrm{C} 4$ & C20 & C29 & C52 & C60 & AGV-1 & AGV-1 \\
\hline $\mathrm{SiO}_{2}$ & 47.31 & 47.31 & 45.86 & 45.80 & 44.13 & 46.28 & 45.58 & 43.54 & 42.80 & 45.93 & 46.19 & 46.48 & 45.18 & 46.26 & 59.25 & 59.07 \\
\hline $\mathrm{TiO}_{2}$ & 2.66 & 2.66 & 2.93 & 1.65 & 2.34 & 1.77 & 1.91 & 2.36 & 2.71 & 2.06 & 1.73 & 1.83 & 1.94 & 1.99 & 1.06 & 1.06 \\
\hline $\mathrm{Al}_{2} \mathrm{O}_{3}$ & 13.55 & 13.03 & 13.76 & 14.21 & 13.02 & 14.10 & 13.74 & 12.29 & 12.12 & 15.64 & 15.02 & 15.70 & 14.55 & 16.08 & 17.15 & 17.30 \\
\hline $\mathrm{Fe}_{2} \mathrm{O}_{3}$ & 1.55 & 4.25 & 3.90 & 2.77 & 2.24 & 1.74 & 1.86 & 6.54 & 3.80 & 2.52 & 1.42 & 1.39 & 3.03 & 1.81 & 4.47 & $* * * 2$ \\
\hline $\mathrm{FeO}$ & 10.45 & 7.83 & 8.32 & 10.71 & 8.97 & 10.35 & 10.88 & 5.74 & 8.82 & 9.73 & 10.49 & 10.13 & 9.36 & 10.65 & 2.06 & $* * *$ \\
\hline $\mathrm{MnO}$ & 0.15 & 0.16 & 0.15 & 0.21 & 0.16 & 0.16 & 0.19 & 0.18 & 0.18 & 0.15 & 0.17 & 0.16 & 0.17 & 0.17 & 0.10 & n.a. \\
\hline $\mathrm{MgO}$ & 9.73 & 9.60 & 9.13 & 10.41 & 10.64 & 10.39 & 10.69 & 13.12 & 12.58 & 8.24 & 9.62 & 8.35 & 10.44 & 7.90 & 1.53 & 1.45 \\
\hline $\mathrm{CaO}$ & 9.87 & 9.61 & 10.12 & 9.99 & 12.08 & 10.58 & 10.42 & 11.30 & 11.09 & 10.44 & 11.31 & 11.62 & 11.07 & 10.48 & 4.94 & 4.99 \\
\hline $\mathrm{Na}_{2} \mathrm{O}$ & 2.92 & 2.82 & 2.65 & 2.85 & 3.09 & 2.58 & 2.96 & 3.26 & 2.60 & 3.38 & 2.88 & 2.87 & 2.30 & 3.10 & 4.25 & n.a. \\
\hline $\mathrm{K}_{2} \mathrm{O}$ & 1.02 & 1.01 & 0.94 & 0.34 & 1.15 & 0.40 & 0.63 & 0.76 & 1.33 & 0.58 & 0.29 & 0.33 & 0.16 & 0.40 & 2.90 & 2.88 \\
\hline $\mathrm{P}_{2} \mathrm{O}_{5}$ & 0.42 & 0.46 & 0.34 & 0.24 & 0.43 & 0.24 & 0.28 & 0.43 & 0.51 & 0.27 & 0.16 & 0.21 & 0.16 & 0.20 & 0.48 & 0.45 \\
\hline $\mathrm{H}_{2} \mathrm{O}^{+}$ & 0.33 & 0.88 & 1.38 & 1.58 & 0.64 & 0.57 & 0.62 & 0.88 & 1.61 & 0.26 & 0.26 & 0.46 & 1.43 & 0.81 & & \\
\hline Total & 99.96 & 99.62 & 99.48 & 100.76 & 98.89 & 99.16 & 99.76 & 100.40 & 100.15 & 99.20 & 99.54 & 99.53 & 99.79 & 99.85 & & \\
\hline Mg No. & 62.4 & 68.6 & 66.2 & 63.4 & 67.9 & 64.1 & 63.6 & 80.3 & 71.8 & 60.1 & 62.0 & 59.5 & 66.5 & 56.9 & BHVO-1 & BHVO-1 \\
\hline $\mathrm{Ni}$ & 352 & 390 & 253 & 425 & 335 & 277 & 361 & 448 & 427 & 163 & 258 & 149 & 355 & 175 & 121 & n.a. \\
\hline $\mathrm{Cr}$ & 349 & 408 & 317 & 361 & 360 & 402 & 378 & 431 & 367 & 109 & 329 & 237 & 346 & 50 & 289 & n.a. \\
\hline V & 263 & 284 & 338 & 229 & 253 & 200 & 241 & 283 & 296 & 190 & 256 & 261 & 242 & 261 & 317 & n.a. \\
\hline $\mathrm{Rb}$ & 31 & 34 & 24 & 9 & 42 & 11 & 22 & 13 & 46 & 17 & 12 & 4 & 5 & 7 & 9.7 & n.a. \\
\hline $\mathrm{Ba}$ & 268 & 301 & 238 & 171 & 491 & 207 & 238 & 524 & 571 & 195 & 106 & 137 & 189 & 150 & 133 & 136 \\
\hline Th & 2.91 & 3.13 & 2.49 & 0.81 & 3.37 & 0.34 & 1.89 & 3.50 & 3.97 & 1.82 & 1.09 & 0.92 & 1.40 & 1.35 & 1.08 & 1.11 \\
\hline $\mathrm{U}$ & 0.86 & 0.84 & 0.38 & 0.22 & 0.92 & 0.08 & 0.52 & 0.97 & 1.18 & 0.49 & 0.27 & 0.18 & 0.11 & 0.29 & 0.42 & 0.42 \\
\hline $\mathrm{Nb}$ & 32 & 32 & 32 & 13 & 49 & 24 & 23 & 45 & 54 & 22 & 12 & 14 & 17 & 17 & 19 & 22 \\
\hline $\mathrm{Ta}$ & 1.9 & 1.9 & 1.9 & 0.73 & 2.7 & 1.7 & 1.3 & 2.5 & 3.0 & 1.4 & 0.70 & 1.0 & 1.3 & 0.98 & 1.16 & 1.3 \\
\hline $\mathrm{La}$ & 26.5 & 27.4 & 25.3 & 10.5 & 33.2 & n.a. & 17.1 & 32.2 & 39.9 & 14.5 & 9.02 & 9.74 & 12.8 & 14.0 & 15.8 & 18.2 \\
\hline $\mathrm{Ce}$ & 53.4 & 55.1 & 52.0 & 22.1 & 59.3 & n.a. & 32.8 & 61.7 & 76.2 & 29.9 & 18.9 & 20.6 & 26.6 & 24.2 & 38.0 & 41.7 \\
\hline $\operatorname{Pr}$ & 7 & 7.19 & 6.88 & 3.25 & 7.54 & n.a. & 4.56 & 7.87 & 9.51 & 4.18 & 2.75 & 3.06 & 3.79 & 3.59 & 5.70 & 6.25 \\
\hline $\mathrm{Pb}$ & 2.0 & 2.1 & 1.9 & 1.3 & 2.5 & 1.9 & 1.2 & 2.3 & 2.6 & 1.2 & 0.7 & 0.9 & 2.0 & 0.9 & 2.05 & 2.20 \\
\hline $\mathrm{Sr}$ & 418 & 397 & 380 & 281 & 545 & 276 & 346 & 520 & 595 & 391 & 326 & 326 & 362 & 327 & 403 & n.a. \\
\hline $\mathrm{Nd}$ & 29.5 & 30.2 & 29.3 & 14.5 & 30.9 & n.a. & 19.4 & 32.1 & 38.9 & 18.0 & 12.4 & 13.8 & 16.5 & 16.1 & 25.2 & 28.5 \\
\hline $\mathrm{Zr}$ & 210 & 215 & 203 & 107 & 162 & n.a. & 114 & 170 & 214 & 124 & 80 & 88 & 102 & 106 & 179 & 192 \\
\hline Hf & 5.14 & 5.16 & 5.04 & 2.62 & 4.03 & n.a. & 3.04 & 4.14 & 5.04 & 3.16 & 2.19 & 2.29 & 2.66 & 2.73 & 4.38 & 4.94 \\
\hline $\mathrm{Sm}$ & 6.64 & 6.69 & 6.72 & 3.86 & 6.63 & n.a. & 4.84 & 6.88 & 8.16 & 4.59 & 3.35 & 3.77 & 4.18 & 4.14 & 6.20 & 7.09 \\
\hline $\mathrm{Eu}$ & 2.17 & 2.17 & 2.20 & 1.41 & 2.21 & n.a. & 1.66 & 2.25 & 2.63 & 1.63 & 1.27 & 1.37 & 1.52 & 1.48 & 2.06 & 2.16 \\
\hline $\mathrm{Gd}$ & 6.74 & 6.79 & 6.82 & 4.46 & 6.76 & n.a. & 5.40 & 6.82 & 7.94 & 5.09 & 3.98 & 4.34 & 4.72 & 4.78 & 6.40 & 7.72 \\
\hline $\mathrm{Tb}$ & 1.00 & 1.01 & 1.03 & 0.72 & 0.97 & n.a. & 0.85 & 1.00 & 1.14 & 0.82 & 0.66 & 0.71 & 0.74 & 0.78 & 0.96 & 1.12 \\
\hline Dy & 5.37 & 5.47 & 5.50 & 4.36 & 5.06 & n.a. & 4.85 & 5.14 & 5.63 & 4.65 & 4.02 & 4.29 & 4.40 & 4.61 & 5.20 & 6.18 \\
\hline $\mathrm{Y}$ & 29.0 & 29.5 & 29.3 & 23.6 & 29.1 & n.a. & 25.3 & 26.2 & 28.4 & 23.9 & 21.0 & 22.2 & 22.2 & 26.7 & 27.6 & 31.9 \\
\hline Но & 1.03 & 1.02 & 1.04 & 0.84 & 0.92 & n.a. & 0.95 & 0.94 & 1.00 & 0.91 & 0.81 & 0.85 & 0.85 & 0.91 & 0.99 & 1.16 \\
\hline $\mathrm{Er}$ & 2.48 & 2.48 & 2.49 & 2.11 & 2.10 & n.a. & 2.32 & 2.21 & 2.30 & 2.23 & 2.01 & 2.09 & 2.05 & 2.28 & 2.40 & 2.76 \\
\hline $\mathrm{Tm}$ & 0.33 & 0.34 & 0.34 & 0.29 & 0.28 & n.a. & 0.33 & 0.29 & 0.29 & 0.31 & 0.28 & 0.29 & 0.28 & 0.32 & 0.33 & 0.38 \\
\hline $\mathrm{Yb}$ & 2.04 & 2.07 & 2.02 & 1.85 & 1.62 & n.a. & 2.05 & 1.77 & 1.77 & 1.96 & 1.76 & 1.83 & 1.78 & 1.99 & 2.02 & 2.30 \\
\hline $\mathrm{Lu}$ & 0.29 & 0.29 & 0.29 & 0.28 & 0.23 & n.a. & 0.30 & 0.25 & 0.24 & 0.29 & 0.25 & 0.27 & 0.26 & 0.29 & 0.29 & 0.33 \\
\hline
\end{tabular}

${ }^{1}$ The rock series are OS (Older), IS (Intermediate), and YS (Younger). The rock names (obtained using the SINCLAS program of Verma et al. (2002) are alkalic basalt (AB), subalkalic basalt (SAB), and basanite (BAS). Major-element data are in weight percent (wt\%); trace elements are in parts per million (ppm). Major-element and $\mathrm{Rb}, \mathrm{Ba}, \mathrm{Sr}, \mathrm{Ni}, \mathrm{Cr}$, and $\mathrm{V}$ data were obtained by XRFS, except $\mathrm{Na}_{2} \mathrm{O}$, which was measured by flame photometry. For the major-element data, an indication of accuracy is given by measured and recommended values (from Potts et al., 1992) for standard rock AGV-1.

${ }^{2}$ The symbol “***" indicates that, for the samples, total Fe was measured by XRFS, and FeO by the ammonium vanadate titration method; $\mathrm{Fe}_{2} \mathrm{O}_{3}$ was calculated from the difference. For AGV-1, the measured value of total Fe as $\mathrm{FeO}$ was 6.27 wt $\%$ and the recommended value (Potts et al., 1992) is $6.08 \mathrm{wt} \%$. For the ICPMS data, accuracy is indicated by the measured and recommended values (mostly from Govindaraju, 1989) for standard rock BHVO-1. For trace elements at $>0.4 \mathrm{ppm}$ in the rock and analyzed by ICPMS, the relative uncertainty for most elements is $3.5 \%$ or better (range is $1-5 \%$ ). Percentage precision for the XRFS data is as follows: $\mathrm{SiO}_{2}=0.55, \mathrm{TiO}_{2}=1.94, \mathrm{Al}_{2} \mathrm{O}_{3}=1.02, \mathrm{FeO}$ total $=1.76, \mathrm{MnO}=3.80, \mathrm{MgO}=1.96, \mathrm{CaO}=0.54, \mathrm{~K}_{2} \mathrm{O}=0.43, \mathrm{P}_{2} \mathrm{O}_{5}=3.80, \mathrm{Ni}=4, \mathrm{Cr}=12, \mathrm{~V}=5, \mathrm{Rb}=7, \mathrm{Ba}=6$. Percentage precision on $\mathrm{Na}_{2} \mathrm{O}$ is $0.90 ;$ n.a. $=$ not analyzed/available. 
TABLE 2. Isotopic and Pb Isotope Dilution Data for Mauritius Lavas

\begin{tabular}{|c|c|c|c|c|c|c|c|c|c|c|}
\hline Sample: & A168 & Al69 & A215 & B5 & B18 & B33 & B34 & $\mathrm{C} 20$ & C29 & C52 \\
\hline${ }^{143} \mathrm{Nd} /{ }^{144} \mathrm{Nd}$ & 0.512841 & 0.512842 & 0.512853 & 0.512875 & 0.512897 & $\begin{array}{l}0.512895 \\
(0.000014)\end{array}$ & 0.512899 & 0.512874 & 0.512882 & 0.512891 \\
\hline$\varepsilon_{\mathrm{Nd}}$ & +3.9 & +3.9 & +4.1 & +4.6 & +5.0 & $\begin{array}{r}+5.0 \\
0.3\end{array}$ & +5.0 & +4.6 & +4.7 & +4.9 \\
\hline${ }^{87} \mathrm{Sr} /{ }^{86} \mathrm{Sr}$ & 0.70429 & 0.70431 & 0.70412 & 0.70372 & 0.70381 & $\begin{array}{c}0.70384 \\
(0.00003)\end{array}$ & 0.70379 & 0.70401 & 0.70376 & 0.70377 \\
\hline $\mathrm{Pb}(\mathrm{ppm})$ & 2.18 & 2.45 & 2.15 & 2.58 & 1.06 & & 2.15 & 0.78 & 0.91 & 0.89 \\
\hline${ }^{206} \mathrm{~Pb} /{ }^{204} \mathrm{~Pb}$ & 18.940 & 18.770 & 19.024 & 19.004 & 18.974 & na & $\begin{array}{l}18.634 \\
(0.005)\end{array}$ & 18.688 & $\begin{array}{l}18.617 \\
(0.005)\end{array}$ & 18.608 \\
\hline${ }^{207} \mathrm{~Pb} /{ }^{204} \mathrm{~Pb}$ & 15.595 & 15.596 & 15.609 & 15.598 & 15.595 & na & $\begin{array}{l}15.569 \\
(0.005)\end{array}$ & 15.569 & $\begin{array}{l}15.580 \\
(0.005)\end{array}$ & 15.571 \\
\hline${ }^{208} \mathrm{~Pb} /{ }^{204} \mathrm{~Pb}$ & 39.024 & 38.843 & 39.113 & 39.133 & 39.088 & na & $\begin{array}{l}38.633 \\
(0.010)\end{array}$ & 38.713 & $\begin{array}{l}38.635 \\
(0.010)\end{array}$ & 38.617 \\
\hline
\end{tabular}

${ }^{2} \mathrm{All}$ isotopic ratios are present-day values. $\varepsilon_{\mathrm{Nd}}=0$ today corresponds to ${ }^{143} \mathrm{Nd} /{ }^{144} \mathrm{Nd}=0.512640$. Nd and Sr isotope data for sample B33 are from Mahoney et al. (1989). Data are reported relative to values of ${ }^{87} \mathrm{Sr} /{ }^{86} \mathrm{Sr}=0.71024$ for $\mathrm{NBS} 987 \mathrm{Sr}$ and ${ }^{143} \mathrm{Nd} /{ }^{144} \mathrm{Nd}=0.511845$ for La Jolla Nd. For Pb isotopes, the total range on $\sim 5 \mathrm{ng}$ loads of NBS 981 in the 2000-2002 period was $\sim 250$ ppm for each ratio for double-spike measurements, and the mean ratios measured are 16.937, 15.492, and 36.710. The total range measured for NBS $987 \mathrm{Sr}$ over this period was \pm 0.000020 ; for La Jolla $\mathrm{Nd}$ it was \pm 0.0000010 ( $0.2 \varepsilon_{\mathrm{Nd}}$ units). Within-run errors on the isotopic data above are less than or equal to the external uncertainties on these standards, except as shown in parentheses.

abundance by isotope dilution, at the University of Hawaii following the methods of Mahoney et al. (1991), except that $\mathrm{Pb}$ isotope measurements employed a double-spike method (Galer, 1999). The isotopic data are presented in Table 2; because of the young ages of all three series, the data are not age-corrected.

\section{Major and Trace Elements}

We used the SINCLAS program (Verma et al., 2002) to calculate normative compositions and $\mathrm{Mg}$ numbers $(\mathrm{Mg \#})$, and to obtain rock names. Three of our samples are classified as subalkalic basalts (Older Series samples A168 and A169, and Younger Series lava C52); these three have normative hypersthene. Eight samples are alkalic basalts; they lack normative hypersthene but contain normative nepheline. Three others (B5, B33 and B34), all from the Intermediate Series, are classified as basanites, with $~ 9-11 \%$ normative nepheline, low $\mathrm{SiO}_{2}$ contents $(<45 \mathrm{wt} \%)$, and relatively high $\mathrm{MgO}$ (11-12 wt\%). Data for all the samples analyzed by Baxter (1972) are plotted in the total alkalis-silica diagram of Le Bas et al. (1986) in Figure 2. The heavy curve is the boundary between the subalkalic and alkalic fields as proposed by Irvine and Baragar (1971). The majority of the data lie in the alkalic basalt field. Several high-MgO samples lie in the picrobasalt and tephrite-basanite fields. $\mathrm{MgO}$ contents and $\mathrm{Mg \#}\left(=\left[\right.\right.$ atomic $\left.\mathrm{Mg} /\left(\mathrm{Mg}+\mathrm{Fe}^{2+}\right)\right]$ x 100 , assuming $\left.\mathrm{Fe}^{3+} / \mathrm{Fe}^{2+}=0.16\right)$ are quite high for most of the samples we analyzed; i.e., most of our rocks are rather primitive. The lowest value for $\mathrm{Mg \#}$ is 56.9 (sample C60), and the two highest values are 80.3 (B33) and 71.8 (B34). Baxter (1975a) interpreted several high-MgO lavas of the Older Series as having accumulated olivine, and concluded (Baxter, 1976) that many high-MgO lavas of the Intermediate Series represent primitive, near-primary liquids.

Figure 3 shows primitive mantle-normalized element patterns for the Mauritius lavas along with the pattern for average Réunion shield-stage tholeiite for comparison. Patterns for the Older Series lavas 


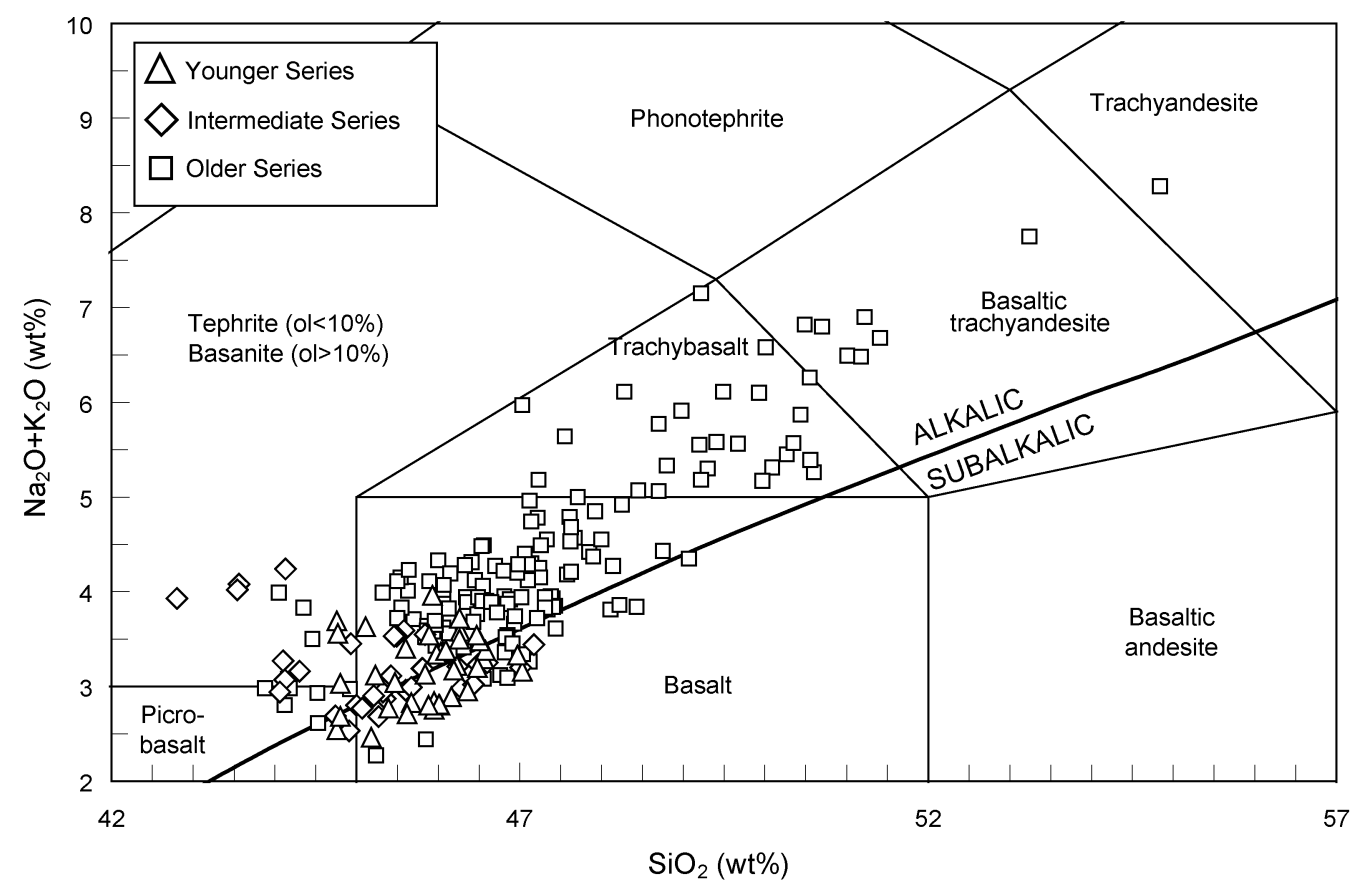

FIG. 2. Data for Mauritius lavas plotted on the total alkalis-silica (TAS) diagram of Le Bas et al. (1986). Abbreviations: ol = normative olivine. Trachytes and trachydacites of the Older Series are not shown.

show small $\mathrm{Pb}$ and $\mathrm{Nb}-\mathrm{Ta}$ peaks, with small troughs at $\mathrm{Sr}$ and, in one case, $\mathrm{P}$ (Fig. 3A). Their strong similarity to the average Réunion pattern is evident, although the Older Series lavas exhibit slightly greater relative enrichment in the highly incompatible elements. The small $U$ peak in the Réunion pattern is also present in the patterns for A168 and A169. However, sample A215 shows a trough at U, probably a result of $\mathrm{U}$ loss caused by alteration (its $\mathrm{H}_{2} \mathrm{O}$ content is $1.38 \%$; Table 1 ).

Baxter (1976) suggested, based on petrographic and chemical data, that most of the Intermediate Series lavas, comprising alkalic basalts, basanites, and nephelinites, were primitive mafic liquids erupted almost unmodified from upper mantle levels, possibly $45-60 \mathrm{~km}$. We did not analyze any Intermediate Series nephelinites, but the alkalic basalt and basanite patterns display a substantial range in slope. Alkalic basalt B19 has a pattern rather similar in overall slope to the average Réunion shield pattern, but that for $\mathrm{B} 1$ is much flatter. Both the B1 and B19 patterns have peaks at NbTa, like the Older Series and Réunion patterns (Fig. 3B). However, whereas B1 shows a $\mathrm{Pb}$ peak, B19 lacks one, and $\mathrm{B} 19$, in particular, is poor in $\mathrm{Zr}$ and $\mathrm{Hf}$ relative to $\mathrm{Nd}$ or $\mathrm{Sm}$. Also, Ba in sample Bl is high relative to $\mathrm{Rb}$ and $\mathrm{Th}$; this may reflect some post-eruptive redistribution of $\mathrm{Rb}$ and/or $\mathrm{Ba}$, or it may be a primary feature because the basanites (Fig. 3C) also have high relative Ba abundances. The most prominent feature of the basanite patterns is their steepness relative to those for the alkalic basalts, the Older Series, and Réunion shield lavas. The basanite patterns also have pronounced $\mathrm{Nb}-\mathrm{Ta}$ peaks, small but distinct $\mathrm{Pb}$ and $\mathrm{U}$ peaks, and slight troughs at $\mathrm{Zr}$-Hf. Sample B33 seems to have lost some $\mathrm{Rb}$ and $\mathrm{K}$ as a result of alteration (its $\mathrm{H}_{2} \mathrm{O}$ content is $0.88 \%$ ). The variable enrichment in the light REE over the heavy REE, and the crossing REE patterns, are suggestive of small but variable extents of partial melting with, at least in some cases, residual garnet in the source $(\mathrm{La} / \mathrm{Yb}=18.19$ to 22.54$)$. This feature is consistent with formation of some of these magmas at depths greater than about $80 \mathrm{~km}$ (e.g., O'Hara et al., 1971).

Patterns of the Younger Series lavas (Figs. 3D and $3 \mathrm{E}$ ) contrast strongly with the steeper ones of the Older Series basalts and especially the 


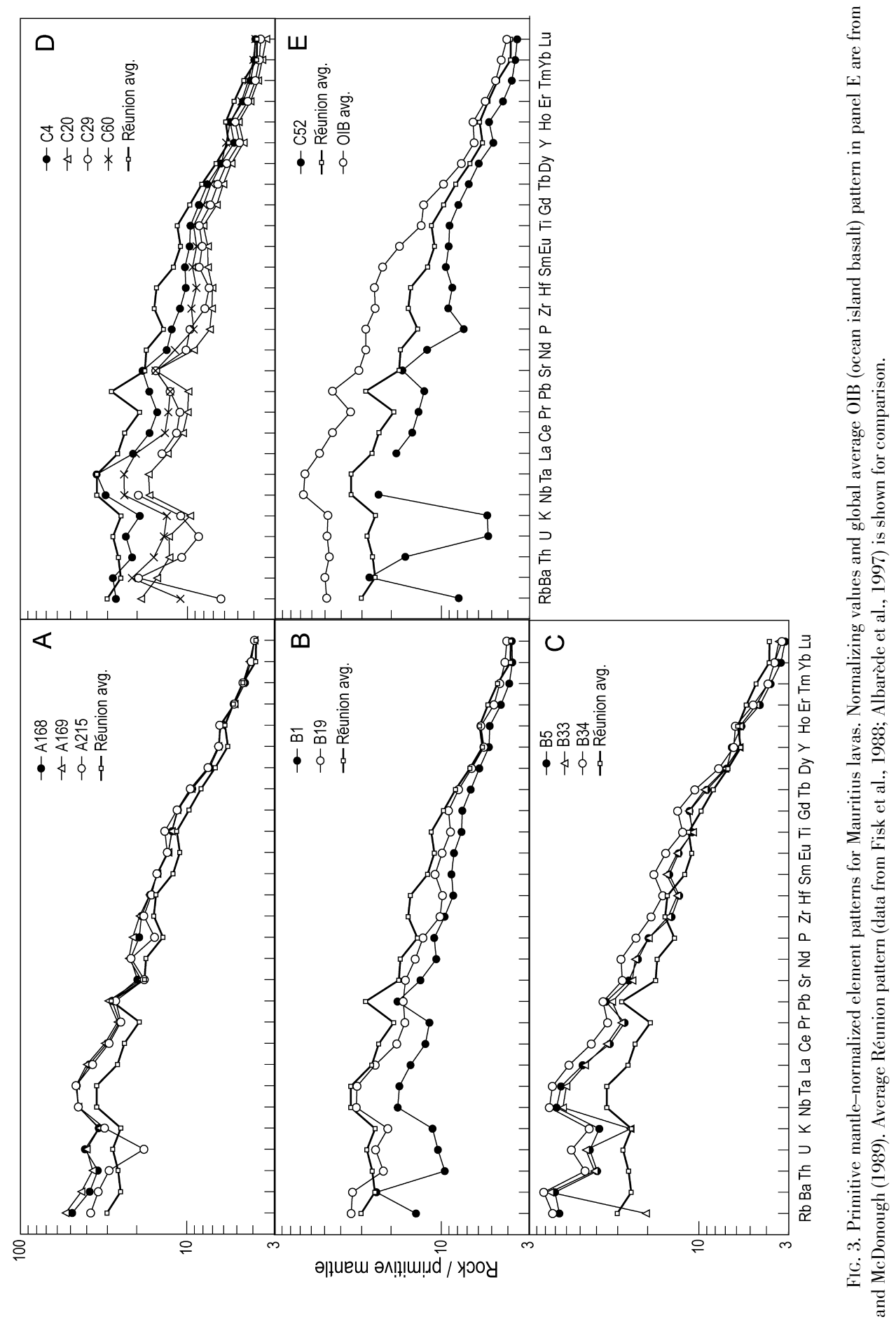



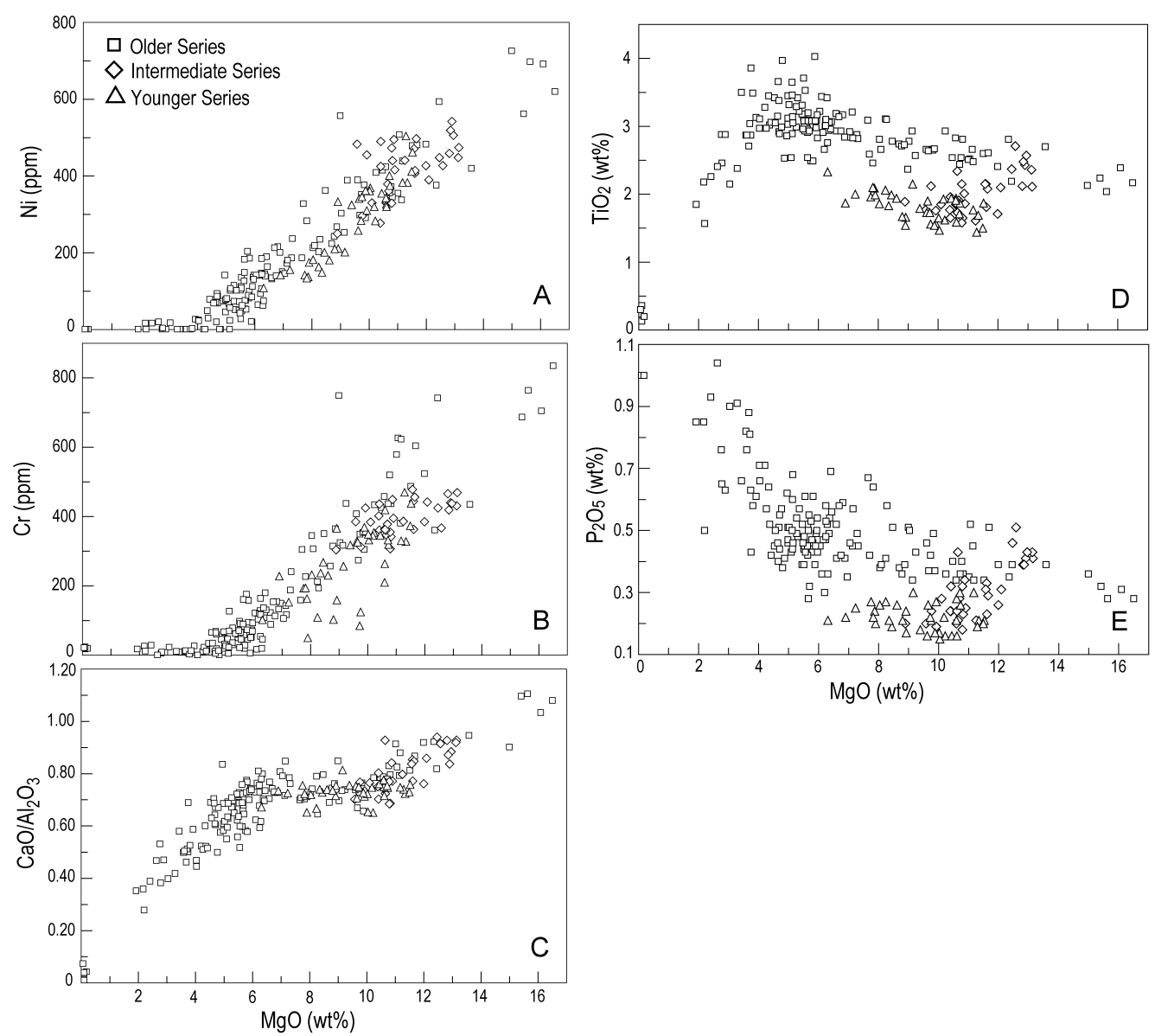

FIG. 4. The variation of $\mathrm{MgO}$ with (A) Ni, (B) Cr, (C) $\mathrm{CaO} / \mathrm{Al}_{2} \mathrm{O}_{3}$, (D) $\mathrm{TiO}_{2}$, and (E) $\mathrm{P}_{2} \mathrm{O}_{5}$. Data are from Baxter (1972) and Table 1.

Intermediate Series basanites. As argued by Baxter (1976), the Younger Series characteristics could reflect either higher degrees of partial melting or low degrees of melting of a source already slightly depleted in the highly incompatible elements. Interestingly, the patterns for the Younger Series alkalic basalts (Fig. 3D) and subalkalic basalt C52 (Fig. 3E) all show peaks at $\mathrm{Sr}$, in addition to Nb-Ta peaks. Several of these lavas appear to have lost variable amounts of K, U, and Rb; sample C52 also has a trough at $\mathrm{P}$, which may be a result of alteration (its $\mathrm{H}_{2} \mathrm{O}$ content is $1.43 \%$ ). Two of the Younger Series samples (C29 in Fig. 3D, and C52 in Fig. 3E) have anomalously low $\mathrm{Nb} / \mathrm{Ta}$ ratios (13.5 and 12.9, respectively, vs. the chondritic value of 17.6; e.g., Sun and McDonough, 1989); these two samples appear to have suffered small amounts of Ta contamination during grinding in tungsten carbide.

Figure 4 shows the variation of several elements with $\mathrm{MgO}$. The positive correlation between $\mathrm{MgO}$ and $\mathrm{Ni}$ (Fig. 4A) and $\mathrm{MgO}$ and $\mathrm{Cr}$ (Fig. 4B) are suggestive of olivine fractionation (with $\mathrm{Cr}$ entering chromite inclusions in olivine; e.g., Frey et al., 2000). Decreasing $\mathrm{CaO} / \mathrm{Al}_{2} \mathrm{O}_{3}$ with decreasing $\mathrm{MgO}$ (Fig. 4C), on the other hand, is indicative of clinopyroxene fractionation. The marked inflections at about 10.5 and $6 \mathrm{wt} \% \mathrm{MgO}$ may indicate that feldspar, with or without some other low-Ca phase, entered and then left (or played a smaller role in) the fractionating assemblage. For the Intermediate Series samples, including the basanites, the high $\mathrm{CaO} / \mathrm{Al}_{2} \mathrm{O}_{3}$ may also reflect the retention of $\mathrm{Al}_{2} \mathrm{O}_{3}$ in 
residual garnet at high pressure (see, e.g., Hirose, 1997). $\mathrm{TiO}_{2}$ and $\mathrm{P}_{2} \mathrm{O}_{5}$ do not show meaningful correlations with $\mathrm{MgO}$ overall (Figs. 4D and 4E). However, for the Older Series, $\mathrm{TiO}_{2}$ shows a good negative correlation with $\mathrm{MgO}$, and the reversal of the $\mathrm{TiO}_{2}$ trend at about $4 \mathrm{wt} \% \mathrm{MgO}$ marks the onset of oxide fractionation. $\mathrm{P}_{2} \mathrm{O}_{5}$ also shows a good negative correlation with $\mathrm{MgO}$ for the Older Series, consistent with apatite fractionation, which is further supported by the appearance of apatite phenocrysts in the most evolved Older Series lavas (Baxter, 1972). The high $\mathrm{Nb} / \mathrm{Y}$ and $\mathrm{Tb} / \mathrm{Yb}$ values of the Intermediate Series basanites (Figs. 5A and 5B) are consistent with them being low-degree partial melts formed at depths where garnet is stable, inasmuch as $\mathrm{Nb}, \mathrm{Tb}$, and $\mathrm{Th}$ are incompatible in garnet, whereas $\mathrm{Y}$ and $\mathrm{Yb}$ behave compatibly in the presence of garnet (e.g., Arth, 1976).

Residual amphibole and phlogopite in the mantle source has been inferred for the rejuvenatedstage Honolulu Volcanics of the island of Oahu, Hawaii, and for some alkalic lavas of the Comores Archipelago, on the basis of depletion in $\mathrm{K}$ relative to other incompatible elements (Clague and Frey, 1982; Späth et al., 1996; Class and Goldstein, 1997; Class et al., 1998). In the presence of residual amphibole, K/Ce increases with increasing melt fraction, because the bulk solid-melt partition coefficient for K exceeds that of Ce (e.g., Francis and Ludden, 1995). No meaningful correlations between $\mathrm{K} / \mathrm{Ce}$ and $\mathrm{Ce}$, or $\mathrm{Rb} / \mathrm{Ce}$ and $\mathrm{Ce}$, are observed for our Mauritius samples (not shown). In part, this may be because of the small sample set for which Ce data are available; moreover, some of the samples have clearly suffered loss of $\mathrm{K}$ and $\mathrm{Rb}$ during alteration. In any case, the data provide no evidence for residual amphibole or phlogopite.

\section{Nd-Sr Isotopes}

Figure 6 compares the Nd-Sr isotopic ratios of the Mauritius lavas to those of mid-ocean ridge basalts (MORB) of the CIR and Carlsberg Ridge, basalts drilled during Leg 115 of the Ocean Drilling Program (Sites 707, 715, 713, and 706), basalts from Texaco drill site SM-1 on the Mascarene Plateau, and the Réunion lavas. Data for the Older Series lavas overlap, or lie very close to, the field defined by Réunion shield lavas. Together with similar $\mathrm{Pb}$ isotope characteristics (see below) and elemental characteristics, this result indicates closely similar mantle sources and petrogenetic evolution
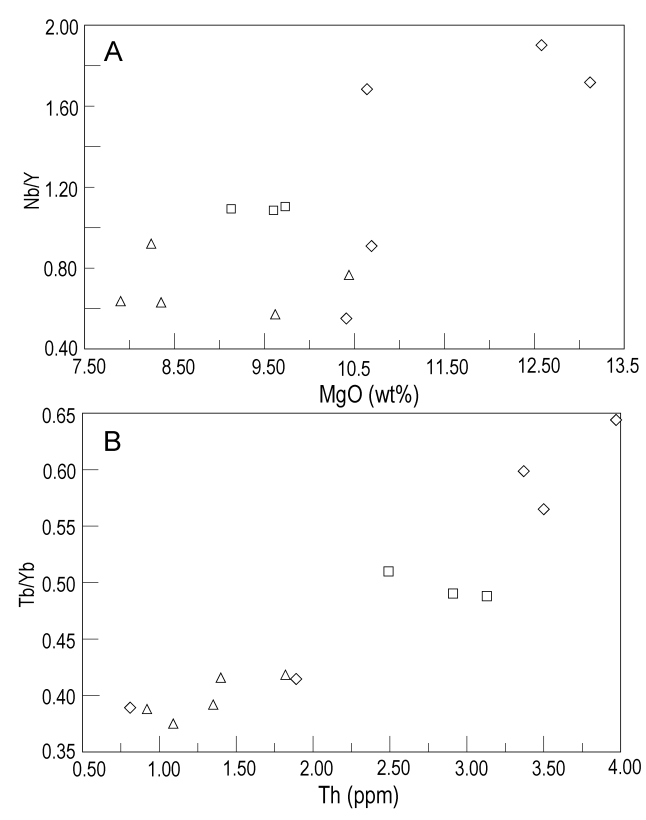

FIG. 5. Variation of (A) $\mathrm{Nb} / \mathrm{Y}$ with $\mathrm{MgO}$ and (B) $\mathrm{Tb} / \mathrm{Yb}$ with Th.

for the Mauritius Older Series and Réunion shield lavas (cf. Peng and Mahoney, 1995).

The Older Series lavas have ${ }^{87} \mathrm{Sr} /{ }^{86} \mathrm{Sr}$ ratios (0.70412-0.70433) consistently higher than those of the Intermediate and Younger Series (0.703690.70401 ), and the three series show a broad inverse relationship in ${ }^{143} \mathrm{Nd} /{ }^{144} \mathrm{Nd}$, with the Older Series lavas having consistently lower ${ }^{143} \mathrm{Nd} /{ }^{144} \mathrm{Nd}$ $\left(0.512827-0.512853, \varepsilon_{\mathrm{Nd}}=+3.6\right.$ to +4.1$)$ than the Intermediate Series $\left(0.512875-0.512899, \varepsilon_{\mathrm{Nd}}+4.6\right.$ to +5.0) and Younger Series lavas (0.5128740.512891, $\varepsilon_{\mathrm{Nd}}+4.6$ to +4.9 ) (Fig. 6). ${ }^{2}$ A similar inverse relationship is observed in many ocean island volcanoes, including Hawaiian volcanoes. Shield-building lavas of the Hawaiian chain have a wide range of isotopic compositions, but they are more radiogenic in $\mathrm{Sr}$ and less radiogenic in $\mathrm{Nd}$ than the post-shield and rejuvenated-stage lavas, which

${ }^{2}$ The sample A181, analyzed by Mahoney et al. (1989), has ${ }^{143} \mathrm{Nd} /{ }^{144} \mathrm{Nd}=0.511876$ relative to ${ }^{143} \mathrm{Nd} /{ }^{144} \mathrm{Nd}=0.511845$ for the La Jolla Nd standard, $\varepsilon_{\mathrm{Nd}}=+4.6$, and ${ }^{87} \mathrm{Sr} /{ }^{86} \mathrm{Sr}=$ 0.70411 . It is not clear whether this sample belongs to the Older or the Intermediate Series, inasmuch as it was collected near the boundary between the two types in a heavily forested area. 


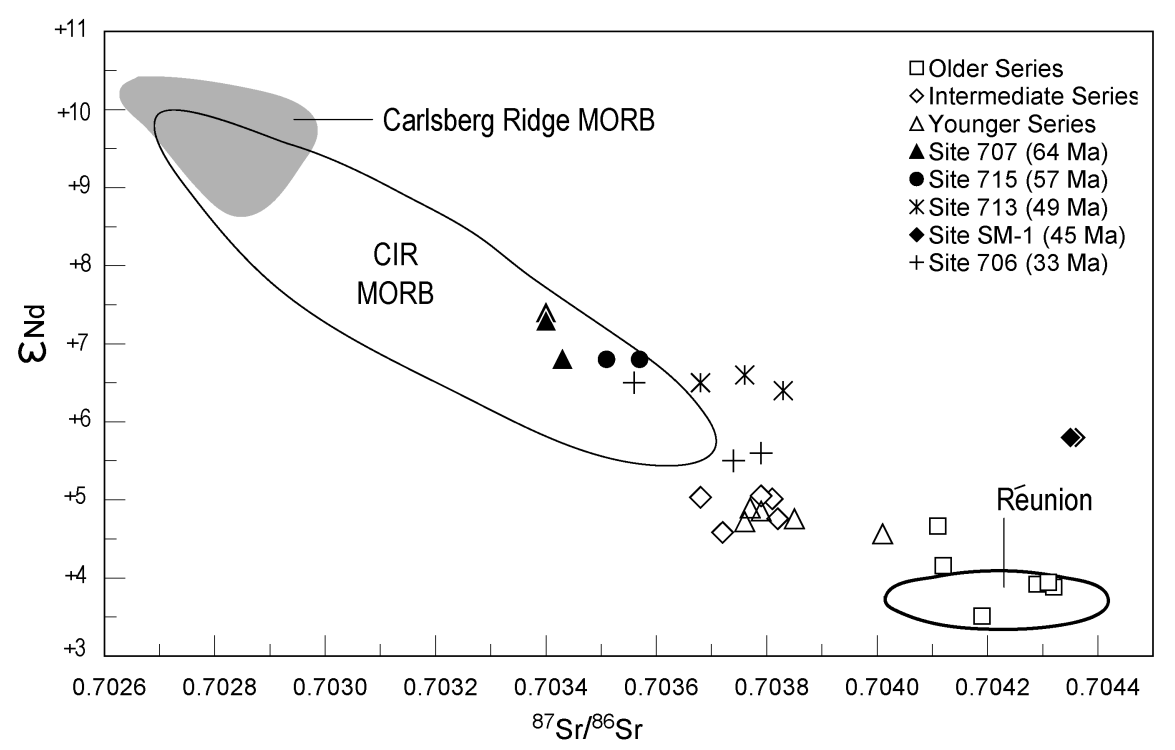

FIG. 6. Nd-Sr isotopic variations. All data are present-day values. Data sources for Mauritius are this study, Mahoney et al. (1989), and Peng and Mahoney (1995). Fields for CIR and Carlsberg Ridge MORB (Ito et al., 1987; Mahoney et al., 1989) and Réunion (Fisk et al., 1988) are shown for comparison, as are data for ODP Leg 115 and Texaco drill site SM1 (White et al., 1990). Ages for the Leg 115 and SM-1 basalts are from Duncan and Hargraves (1990).

also are more alkalic than shield-stage lavas. These features of post-shield and rejuvenated-stage volcanism have been interpreted as indicating either lowdegree melting or recent $(<400 \mathrm{Ma})$ mantle metasomatism involving material from comparatively MORB-like mantle (e.g., Clague and Frey, 1982; Stille et al., 1983; Chen and Frey, 1983, 1985; Feigenson, 1984; Roden et al., 1984; Clague and Dalrymple, 1988; Maaløe et al., 1992; Reiners and Nelson, 1998; Frey et al., 2000).

$\mathrm{Nd}$ and $\mathrm{Sr}$ isotopic ratios of the Intermediate and Younger Series Mauritius lavas overlap, and cluster in a small area (consistent with a common, relatively homogeneous mantle source for both) between the Older Series and Réunion values and the CIR MORB field in Figure 6. The Intermediate and Younger Series may therefore represent melts of a mixed mantle source (cf. Mahoney et al., 1989). Their relative closeness to CIR MORB isotopic compositions is also consistent with their helium isotopic ratios. Hanyu et al. (2001) reported that ${ }^{3} \mathrm{He} /{ }^{4} \mathrm{He}$ ratios of both volcanoes on Réunion are uniform (12$13.5 R_{a}$, where $R_{a}$ is the atmospheric ${ }^{3} \mathrm{He} /{ }^{4} \mathrm{He}$ ratio) regardless of ${ }^{4} \mathrm{He}$ content and sample age, and that values for the Mauritius Older Series lavas are very similar, around $11.5 R_{a}$. In contrast, the Intermedi- ate and Younger Series (and Rodrigues) lavas have ${ }^{3} \mathrm{He} /{ }^{4} \mathrm{He}\left(6.5-8.4 R_{a}\right)$ similar to Indian MORB ratios.

The Leg 115 and SM-1 basalts have higher $\varepsilon_{\mathrm{Nd}}$ values than the Intermediate and Younger Series lavas, within or close to the CIR MORB range (Fig. 6). Values for the youngest drill site, Site 706 (33 $\mathrm{Ma}$ ), are closest to those of Mauritius and Réunion. White et al. (1990) argued that, as a group, the $\varepsilon_{\mathrm{Nd}}$ values of the Leg 115 basalts and Réunion showed an overall decrease, and ${ }^{87} \mathrm{Sr} /{ }^{66} \mathrm{Sr}$ a rough increase, with decreasing age. Within the framework of the mantle plume model for ocean island volcanism (e.g., Richards et al., 1989), they interpreted this trend as reflecting progressively decreasing entrainment of asthenospheric (MORB-source) mantle by the upwelling plume. Noting the relatively high Sr isotope values of several of the drilled samples, they concluded that ${ }^{87} \mathrm{Sr} /{ }^{86} \mathrm{Sr}$ also may have been variably increased by seawater alteration. Nd isotopic ratios are not affected by low to moderate levels of seawater alteration, however, and do not appear to vary systematically with age, except that lavas of the two oldest sites (at 64 and $57 \mathrm{Ma}$ ) have slightly higher $\varepsilon_{\mathrm{Nd}}$ than those of the three younger sites (49$33 \mathrm{Ma}$ ). In any case, it is not clear that the drill sites recovered shield-stage lavas. Given that the 


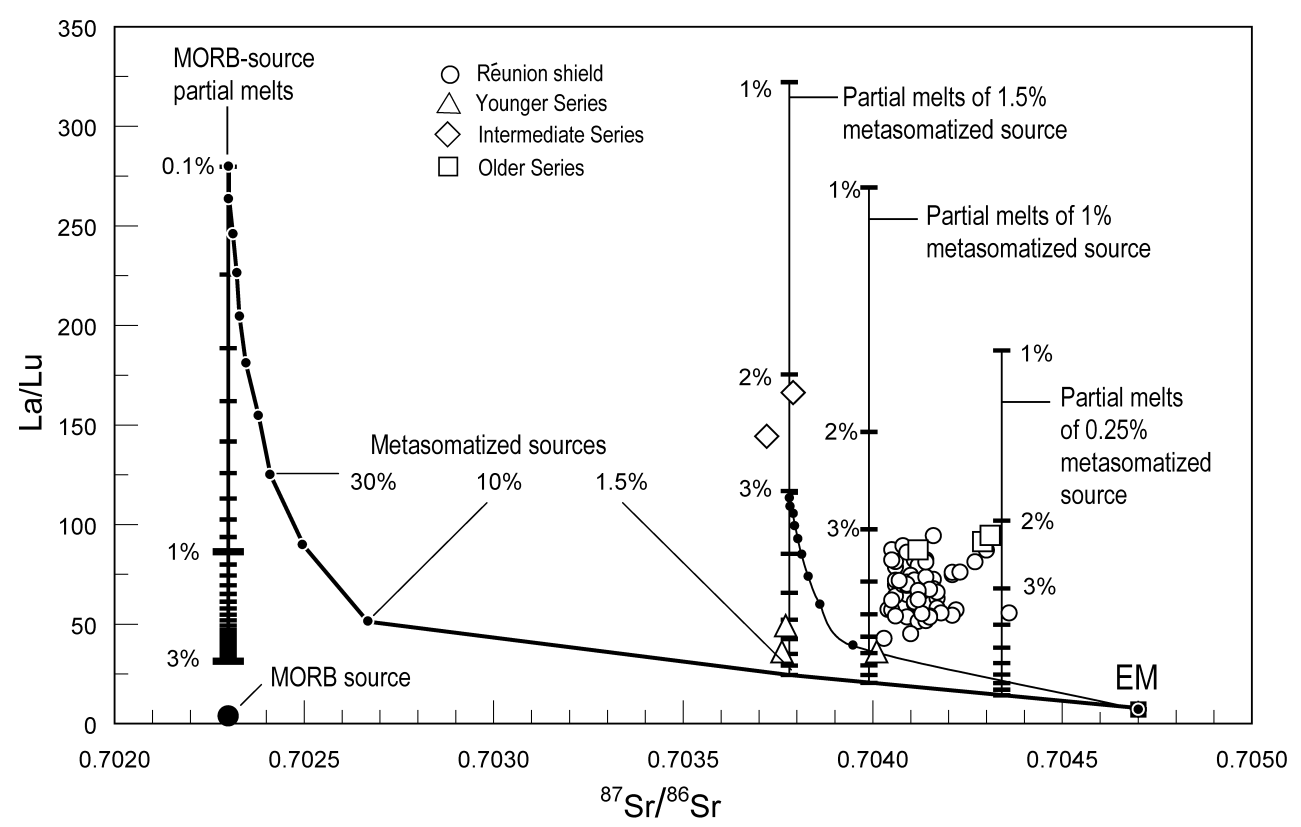

FIG. 7. Illustration of MORB-source and EM partial melting and mixing model for the Mauritius lavas. Data for Réunion shield lavas are also shown (from Fisk et al., 1988; Albarède et al., 1997). The $K_{d}$ values used are from Reiners and Nelson (1998): for La, olivine/melt $=0.00045$, orthopyroxene $/$ melt $=0.00125$, clinopyroxene $/ \mathrm{melt}=0.037$, and garnet $/ \mathrm{melt}=0.007$; for Lu, olivine $/$ melt $=0.00315$, orthopyroxene $/$ melt $=0.049$, clinopyroxene $/ \mathrm{melt}=0.235$, and garnet $/ \mathrm{melt}=5.6$; for Sr, olivine $/$ melt $=0.0015$, orthopyroxene $/$ melt $=0.016$, clinopyroxene $/ \mathrm{melt}=0.1$, and garnet $/ \mathrm{melt}=$ 0.008 .

post-shield Intermediate and Younger Series lavas of Mauritius are more MORB-like in Nd-Sr isotopic characteristics than the shield-stage Older Series, it is possible, perhaps likely, that the drill-site lavas represent post-shield volcanism and that shieldstage lavas were not penetrated during drilling.

\section{A Partial Melting-Mixing Model}

Chen and Frey $(1983,1985)$ explained the transition from shield-stage to post-shield volcanism in the Haleakala Volcano of Maui, Hawaii, with a mixing model in which the proportion of MORB-source mantle to plume mantle increases after the end of the shield stage. Roden et al. (1984) invoked solidmelt mixing, and interpreted the rejuvenated-stage Honolulu Volcanics of Oahu as products of mixing between melts of a MORB-type mantle source and the plume. They estimated that the MORB-type mantle melted to $\sim 0.3 \%$, and that the mixture contained $\sim 2.5 \%$ of these partial melts. Others have proposed mixing of relatively high-degree plume- derived melts with smaller-degree MORB-source melts (e.g., Feigenson, 1984; Clague and Dalrymple, 1988). Whatever the source of the low- $\varepsilon_{\mathrm{Nd}}$, high- ${ }^{87} \mathrm{Sr} /{ }^{86} \mathrm{Sr}$ mantle component (plume or otherwise) and the MORB-like mantle, there is consensus that mixing of mantle sources and/or melts is required to explain the inverse relationships in isotopic ratios and incompatible element abundances between Hawaiian shield and post-shield or rejuvenated-stage lavas.

In Figure 7, we summarize a petrogenetic model for the Mauritius lavas, which is a modified version of that used by Chen and Frey (1983). The model invokes two mixing end members, one of which is MORB-source mantle and the other a mantle source (EM) with bulk-Earth-like $\mathrm{Sr}$ and $\mathrm{Nd}$ isotope ratios. The physical nature of these sources can have variable interpretations. For example, in the mantle plume model (e.g., Richards et al., 1989; Campbell and Griffiths, 1990), EM can represent an upwelling deep mantle plume and the MORB source can represent mantle entrained by the plume or it can be 
lower oceanic lithosphere under an island. In nonplume models (e.g., Smith, 1993; Anderson, 1995, 1996; Smith and Lewis, 1999), EM can represent detached continental lithospheric mantle or a shallow "perisphere," whereas the MORB source can be the oceanic lithosphere or sub-perispheric convecting mantle. Our model postulates metasomatism of EM by low-degree partial melts of the MORB source.

To a first order, the Mauritius and Réunion lavas can be explained as partial melts of variably metasomatized EM sources, or as mixtures of these partial melts from the MORB source and EM. Figure 7 illustrates the model in terms of $\mathrm{La} / \mathrm{Lu}$ and ${ }^{87} \mathrm{Sr} /{ }^{86} \mathrm{Sr}$, parameters used by Reiners and Nelson (1998) to model the Koloa Volcanics of Kauai, Hawaii. As assumed by Reiners and Nelson (1998), the MORB source has the following composition: $\mathrm{La}=0.206$ ppm, $\mathrm{Lu}=0.054 \mathrm{ppm}, \mathrm{Sr}=13.2 \mathrm{ppm}$, and ${ }^{87} \mathrm{Sr} /{ }^{86} \mathrm{Sr}=$ 0.70230. EM has the following composition: $\mathrm{La}=$ $0.71 \mathrm{ppm}, \mathrm{Lu}=0.1 \mathrm{ppm}, \mathrm{Sr}=23.7 \mathrm{ppm}$, and ${ }^{87} \mathrm{Sr} /$ ${ }^{86} \mathrm{Sr}=0.70470$. Non-modal, equilibrium (batch) melting of the MORB source mantle was assumed. The initial mode of the MORB source was taken to be $65 \%$ olivine, $24 \%$ orthopyroxene, $6 \%$ clinopyroxene, and $5 \%$ garnet, and the melts to correspond to $10 \%$ olivine, $10 \%$ orthopyroxene, $40 \%$ clinopyroxene, and $40 \%$ garnet. Partition coefficient $\left(K_{d}\right)$ values used for $\mathrm{La}, \mathrm{Lu}$, and $\mathrm{Sr}$ are given in Figure 7.

The constant ${ }^{87} \mathrm{Sr} /{ }^{86} \mathrm{Sr}$ vertical line above the MORB source point shows how $\mathrm{La} / \mathrm{Lu}$ varies as a function of melt fraction $(F)$ for 0.1-3\% melting of the MORB source. A $0.1 \%$ MORB-source partial melt has $\mathrm{La}=49.3 \mathrm{ppm}, \mathrm{Lu}=0.176 \mathrm{ppm}$, and $\mathrm{Sr}=$ $1086 \mathrm{ppm}$. The large hyperbola shows various binary mixtures of this $0.1 \%$ partial melt and EM (dots mark 10\% increments). Different points on this curve therefore represent EM metasomatized to varying amounts by a $0.1 \%$ MORB-source melt. Five of these metasomatized EM sources (30\%, $10 \%, 1.5 \%, 1 \%$, and $0.25 \%$ ) are indicated by labels. The $1.5 \%$ metasomatized source, for example, has $\mathrm{La}=1.44 \mathrm{ppm}, \mathrm{Lu}=0.10 \mathrm{ppm}, \mathrm{Sr}=39.6 \mathrm{ppm}$, and ${ }^{87} \mathrm{Sr} /{ }^{86} \mathrm{Sr}=0.70378$. The constant ${ }^{87} \mathrm{Sr} /{ }^{86} \mathrm{Sr}$ vertical line rising from it shows the compositions of various partial melts (1-8\%) of this source. Data for four Mauritius Younger and Intermediate Series samples plot near this line; the two Intermediate Series data points (for basanites B5 and B33) can be interpreted as representing $\sim 2.5 \%$ partial melts of the $1.5 \%$ metasomatized source, whereas the two Younger
Series samples (basalts C29 and C52) would represent larger amounts of melting (6.5-8\%). On the other hand, the data point for Younger Series alkalic basalt $\mathrm{C} 20$ (with higher ${ }^{87} \mathrm{Sr} /{ }^{66} \mathrm{Sr}=0.70401$ ) is consistent with $7 \%$ melting of a $1 \%$ metasomatized source. Alternatively, this lava composition can be interpreted as a second-stage mixture lying on a mixing curve between a $3 \%$ partial melt of the $1.5 \%$ metasomatized source and pure EM, the proportion of the $3 \%$ partial melt in the mixture being $~ 8 \%$.

Figure 7 also shows partial melts of a $0.25 \%$ metasomatized EM source, with $\mathrm{La}=0.83 \mathrm{ppm}, \mathrm{Lu}$ $=0.10 \mathrm{ppm}, \mathrm{Sr}=26.4 \mathrm{ppm}$, and ${ }^{87} \mathrm{Sr} /{ }^{86} \mathrm{Sr}=0.70434$. Data for the Older Series and Réunion shield lavas are completely bounded by the lines representing melting of $1 \%$ and $0.25 \%$ metasomatized sources, at melt fractions between 2 and 6\%. All Older Series and Réunion lavas can therefore be interpreted as 2-6\% partial melts of an EM source that is $1 \%$ to $0.25 \%$ metasomatized by a $0.1 \%$ partial melt of the MORB source. Interpretation of the Older Series and Réunion lavas as second-stage mixtures is also possible. All the data are bounded by the mixing curves between a $3 \%$ partial melt of the $1.5 \%$ metasomatized source and EM (Fig. 7), and a $0.1 \%$ partial melt of the $1.5 \%$ metasomatized source and EM (not shown). Thus, the shield lavas can also be interpreted as blends of: (1) EM, and (2) variable but lowdegree (0.1-3\%) partial melts of a source that itself is a 1.5:98.5 mixture of a $0.1 \%$ partial melt of a MORB source and EM. Lacking further evidence, we prefer to interpret the Mauritius (and Réunion) shield lavas as simple partial melts of variable $(1.5 \%-0.25 \%)$ first-stage mixtures of EM and a $0.1 \%$ MORB-source partial melt.

\section{Pb Isotopes}

As with $\mathrm{Nd}$ and $\mathrm{Sr}$ isotopes, the $\mathrm{Pb}$ isotope ratios of the Older Series lavas closely resemble those of Réunion shield lavas, although covering a slightly wider range than yet measured for Réunion (the Réunion field in Figure 8 encloses data for seven samples). Very small differences in ${ }^{207} \mathrm{~Pb} /{ }^{204} \mathrm{~Pb}$ $(<0.01$; Fig. 8D) between the Older Series and Réunion data may simply represent inter-laboratory bias; indeed, the differences are within analytical error for Peng and Mahoney's (1995) two earlier Older Series analyses that were not made by the double-spike method. The $\mathrm{Pb}$ isotopic ratios of the three Intermediate Series lavas have a significantly greater range $\left({ }^{206} \mathrm{~Pb} /{ }^{204} \mathrm{~Pb}\right.$ varies from 18.634 to 


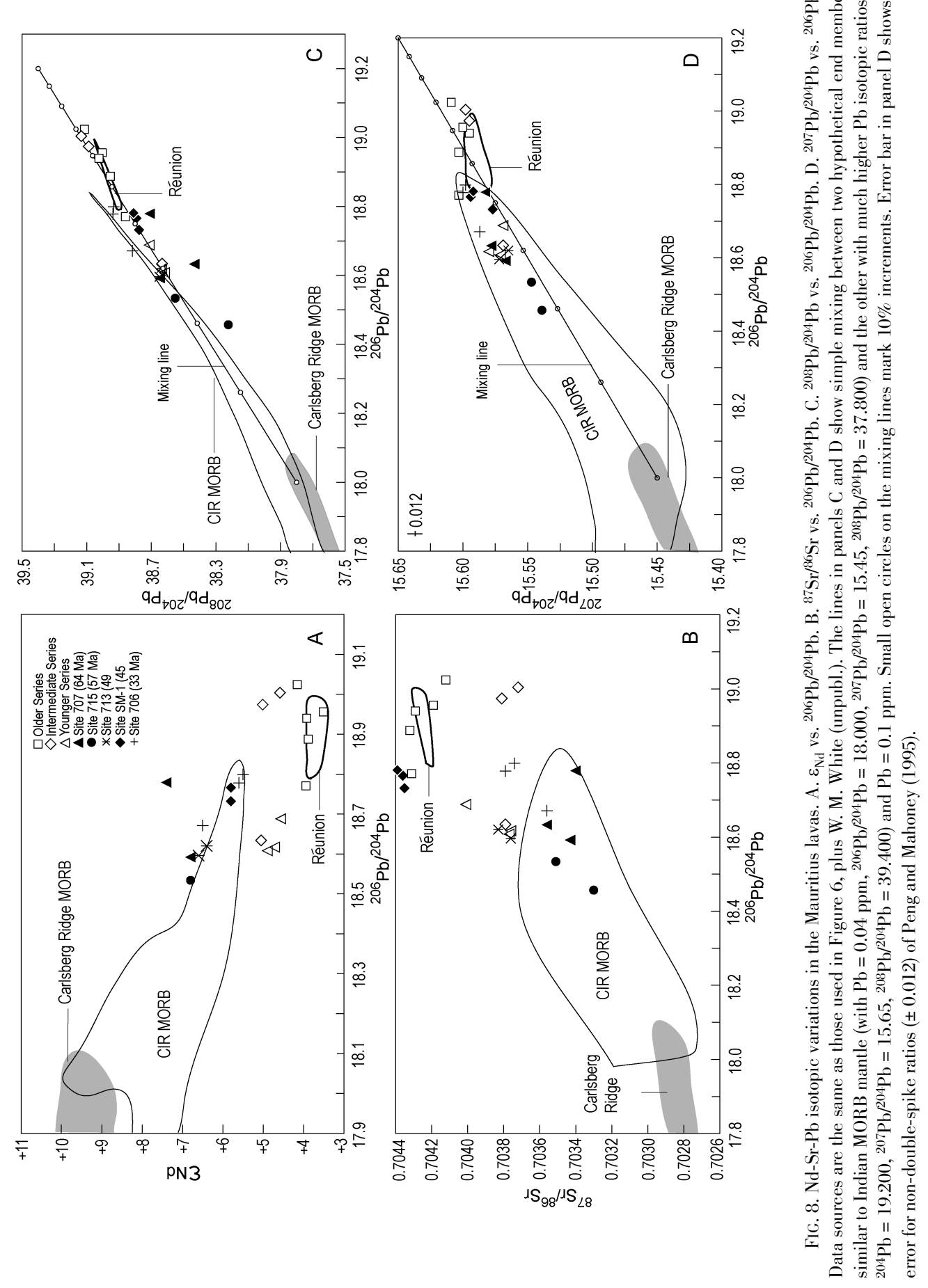




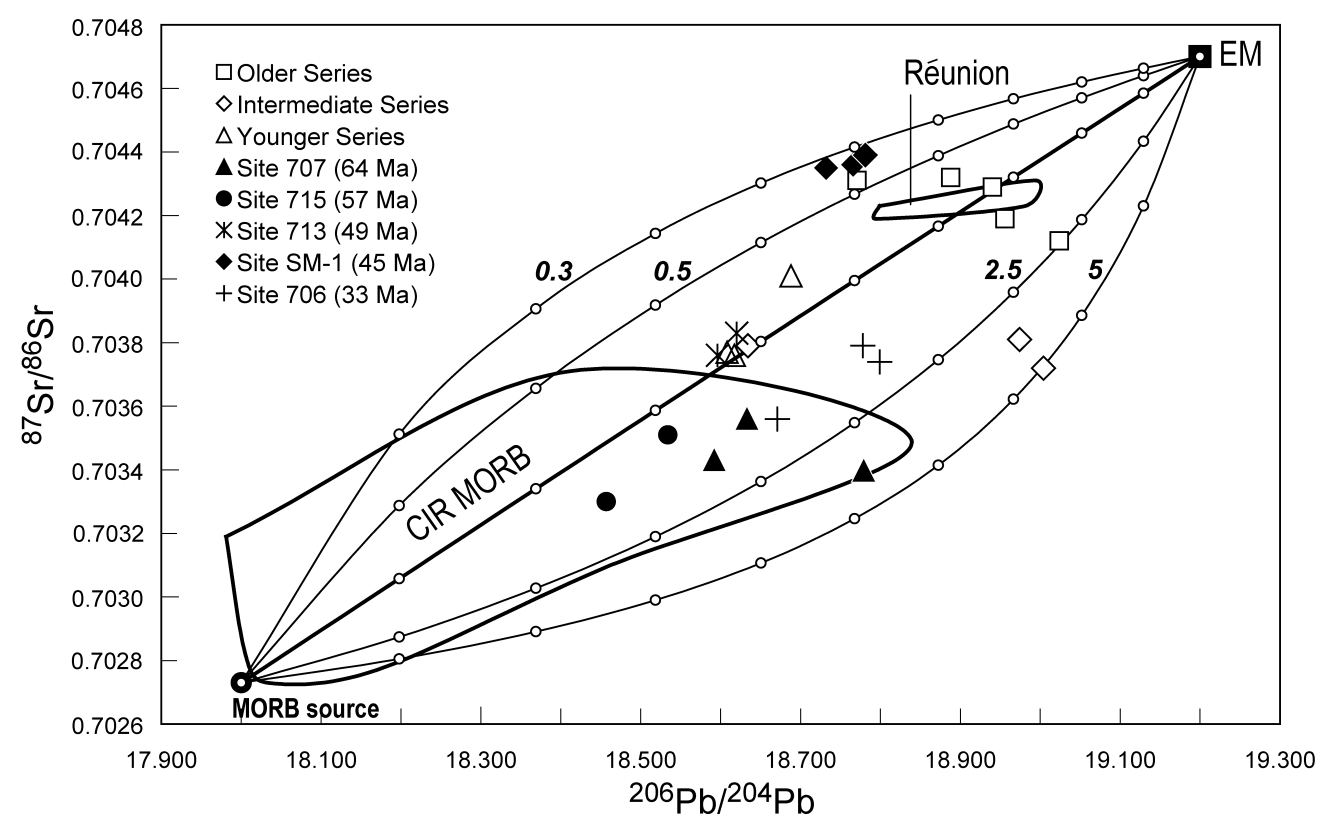

FIG. 9. Small open circles on the mixing curves mark $10 \%$ mixing increments, and the ratio of the $\mathrm{Sr} / \mathrm{Pb}$ values of the two mixing end members is shown beside each curve. For ratios of 5, 2.5, 0.5, and 0.3, the required $\mathrm{Sr}$ concentrations in the "MORB source" are $66.8 \mathrm{ppm}, 33.4 \mathrm{ppm}, 6.68 \mathrm{ppm}$, and $4.00 \mathrm{ppm}$, respectively, assuming the $\mathrm{Pb}$ concentration of the MORB source is constant at $0.04 \mathrm{ppm}$, and that the $\mathrm{Pb}$ and $\mathrm{Sr}$ concentrations of EM are constant, at 0.071 and 23.7 ppm, respectively. Data sources are the same as those in Figure 8.

19.004), from values lower than any measured for the Older Series to almost as high as the highest Older Series value. In contrast, the three Younger Series samples that we analyzed have relatively low $\mathrm{Pb}$ isotope ratios that vary only slightly $\left({ }^{206} \mathrm{~Pb} / 204 \mathrm{~Pb}=\right.$ 18.608 to 18.688). If the Intermediate and Younger Series lavas were derived from a common mantle source rather homogeneous in $\mathrm{Nd}$ and $\mathrm{Sr}$ isotopes, it would seem to have possessed considerable $\mathrm{Pb}$ isotopic heterogeneity. In the previous section, we assumed that the two mantle end-members each had a single, fixed isotopic and elemental composition (i.e., each could be represented as a point on chemical and isotopic diagrams); however, the range exhibited by the Mauritius, Réunion, and drill-site lavas in $\varepsilon_{\mathrm{Nd}}{ }^{87} \mathrm{Sr} /{ }^{86} \mathrm{Sr}-{ }^{206} \mathrm{~Pb} /{ }^{204} \mathrm{~Pb}$ space (Figs. 8A and $8 \mathrm{~B}$ ) indicates that one or both end-members would have to have at least a modest range of compositions. The same can be seen from plots of ${ }^{208} \mathrm{~Pb} /$ ${ }^{204} \mathrm{~Pb}$ vs. ${ }^{206} \mathrm{~Pb} /{ }^{204} \mathrm{~Pb}$ (Fig. 8C) and ${ }^{207} \mathrm{~Pb} / 204 \mathrm{~Pb}$ vs. ${ }^{206} \mathrm{~Pb} /{ }^{204} \mathrm{~Pb}$ (Fig. 8D).

Assuming for the moment that each of the two end-members were isotopically homogeneous, however, the heavy line in Figure 9 is a mixing curve between a MORB source (assumed to have $\mathrm{Sr}=13.2$ ppm, $\mathrm{Pb}=0.04 \mathrm{ppm},{ }^{87} \mathrm{Sr} /{ }^{86} \mathrm{Sr}=0.70273,{ }^{206} \mathrm{~Pb} /$ ${ }^{204} \mathrm{~Pb}=18.000$ ) and EM (assumed to have $\mathrm{Sr}=23.7$ ppm, $\mathrm{Pb}=0.071 \mathrm{ppm},{ }^{87} \mathrm{Sr} /{ }^{86} \mathrm{Sr}=0.70470,{ }^{206} \mathrm{~Pb} /$ $\left.{ }^{204} \mathrm{~Pb}=19.200\right)$. Elemental abundances in the two end-members are based on Sun and McDonough (1989), and EM is similar to their estimate of primitive mantle, but the EM value of 19.200 for ${ }^{206} \mathrm{~Pb} /$ ${ }^{204} \mathrm{~Pb}$ is arbitrarily chosen to exceed the highest value measured for the Mauritius samples. This value is higher than estimates for primitive mantle but close to that of the postulated "Common" or "C" mantle component (Hanan and Graham, 1996). The chosen ${ }^{87} \mathrm{Sr} /{ }^{86} \mathrm{Sr}$ and ${ }^{206} \mathrm{~Pb} / 204 \mathrm{~Pb}$ ratios of the MORB source end-member are nearly identical with those of CIR MORB sample ANTP131-14 $\left(\varepsilon_{\mathrm{Nd}}=+10.0\right.$, ${ }^{87} \mathrm{Sr} /{ }^{86} \mathrm{Sr}=0.70273,{ }^{206} \mathrm{~Pb} / 204 \mathrm{~Pb}=18.033$; Mahoney et al., 1989). The heavy mixing curve is nearly straight, inasmuch as $\mathrm{Sr} / \mathrm{Pb}$ is about equal in the two end-members. For mixing curves that encompass the total range of compositions observed, the $\mathrm{Sr} / \mathrm{Pb}$ ratios of the two end-members must be significantly different. Four other curves in Figure 9 represent mixtures assuming that $\mathrm{Sr} / \mathrm{Pb}$ in the MORB source 
varies from 5 times to 0.3 times the $\mathrm{Sr} / \mathrm{Pb}$ value in EM; this range is necessary for the mixing curves to encompass the $\mathrm{Sr}-\mathrm{Pb}$ isotopic range exhibited by the Mauritius, Réunion, and drill-site samples. Isotopically MORB-like end-members with higher $\mathrm{Sr} / \mathrm{Pb}$ than EM could represent appropriately plagioclaseenriched cumulate rocks within the oceanic lithosphere (see e.g., Frey et al., 2002), whereas MORBlike end-members with lower $\mathrm{Sr} / \mathrm{Pb}$ than EM could be the complementary plagioclase-poor rocks (olivine-clinopyroxene cumulates?). However, such an explanation appears untenable because, although undoubtedly modified somewhat by crystal fractionation, the measured $\mathrm{Sr} / \mathrm{Pb}$ values among the Mauritius samples vary by only a factor of 3.2 (range of $\mathrm{Sr} /$ $\mathrm{Pb}$ is 145 to 466 ), and do not correlate with ${ }^{87} \mathrm{Sr} /$ ${ }^{86} \mathrm{Sr}$. Thus, end members that are isotopically somewhat heterogeneous again appear to be required.

Note that the Older Series, Intermediate Series, and Réunion arrays in Figure 9 trend across mixing curves. This behavior can be explained if one or both of the two end members are isotopically somewhat heterogeneous in $\mathrm{Pb}$ isotopes. Alternatively, the range in ${ }^{206} \mathrm{~Pb} /{ }^{204} \mathrm{~Pb}$ at similar $\mathrm{Sr}$ and $\mathrm{Nd}$ isotope ratios could partly represent radiogenic ingrowth since the mixing event, assuming that somewhat variable $\mathrm{U} / \mathrm{Pb}$ ratios were produced in different parts of the metasomatized source. The ${ }^{206} \mathrm{~Pb} /{ }^{204} \mathrm{~Pb}$ ratio tends to evolve much faster than ${ }^{87} \mathrm{Sr} /{ }^{86} \mathrm{Sr}$ and $\varepsilon_{\mathrm{Nd}}$, because parent-daughter ratios in the ${ }^{238} \mathrm{U}$ ${ }^{206} \mathrm{~Pb}$ system tend to be large (the range in our samples is 2.58 [for B18] to 28.7 [for B34]) and the halflife of ${ }^{238} \mathrm{U}$ is much shorter than those of ${ }^{87} \mathrm{Rb}$ and ${ }^{147} \mathrm{Sm}$ (by a factor of more than 10 and 23 , respectively). For example, a relatively small difference in source ${ }^{238} \mathrm{U} / 204 \mathrm{~Pb}$ of only 5 will lead to a difference in ${ }^{206} \mathrm{~Pb} /{ }^{204} \mathrm{~Pb}$ of 0.25 , the maximum range measured for the Older Series, in 314 m.y. Over the same period, the maximum differences observed in ${ }^{147} \mathrm{Sm} /{ }^{144} \mathrm{Nd}$ and ${ }^{87} \mathrm{Rb} /{ }^{66} \mathrm{Sr}$ for the Older Series lavas would lead to $\mathrm{Nd}$ and $\mathrm{Sr}$ isotopic differences of only $0.3 \varepsilon_{\mathrm{Nd}}$ units and 0.00022 , respectively. Unfortunately, a direct test of this possibility is not possible, because magmatic and alteration processes have variably modified the source-derived ${ }^{238} \mathrm{U} / 204 \mathrm{~Pb}$ signal in the Mauritius samples. However, general support is provided by the very small observed range in ${ }^{207} \mathrm{~Pb} /{ }^{204} \mathrm{~Pb}$ relative to that in ${ }^{206} \mathrm{~Pb} /{ }^{204} \mathrm{~Pb}$ for the Older Series samples. This variation in ${ }^{207} \mathrm{~Pb} /{ }^{204} \mathrm{~Pb}$ (0.014) is effectively the same as the largest analytical uncertainties on the data (i.e., \pm 0.012 on Peng and Mahoney's [1995] data); the Réunion data also define a rather flat field (Fig. 8D). This feature is qualitatively consistent with radiogenic ingrowth of $\mathrm{Pb}$ following a metasomatic event in the not too distant past; for example, the difference in ${ }^{238} \mathrm{U} / 204 \mathrm{~Pb}$ of 5 used in the above example corresponds to a ${ }^{235} \mathrm{U} / 204 \mathrm{~Pb}$ difference of 0.036 , which would lead in 314 m.y. to a difference of only 0.013 in ${ }^{207} \mathrm{~Pb} /{ }^{204} \mathrm{~Pb}$.

\section{Conclusions}

The volcanic, petrological, and geochemical evolution of Mauritius is similar to that of many ocean islands worldwide. The Older Series lavas (shieldbuilding stage) of Mauritius are closely similar to those of Réunion Island in major- and trace-element and $\mathrm{Nd}-\mathrm{Sr}-\mathrm{Pb}$ isotopic compositions. The postshield Intermediate and Younger Series lavas have overlapping $\mathrm{Nd}-\mathrm{Sr}$ isotopic compositions that are slightly more MORB-like than those of the Older Series; their $\mathrm{Pb}$ isotope ratios also extend to more MORB-like values, but $\mathrm{Pb}$ isotope ratios for the Intermediate Series cover nearly the full range observed for all three series. Most Intermediate Series lavas are strongly enriched in highly incompatible elements relative to moderately incompatible ones, but the Younger Series lavas display much less relative enrichment and have low concentrations of incompatible elements. Post-shield lavas with incompatible element enrichment deriving from mantle sources with long-term relative depletion in incompatible elements (as reflected in isotopic ratios) have been observed in ocean islands worldwide (e.g., Hawaii). A partial melting and mixing model for the Mauritius lavas relates them to various extents of partial melting and mixing between a MORB source and a source (EM) with bulk-Earth-like elemental and Nd-Sr isotopic characteristics and a "C"-like $\mathrm{Pb}$ isotopic signature. Many characteristics of the Mauritius and Réunion lavas can be explained if these lavas represent 28\% partial melts of an EM source that had been 1.5$0.25 \%$ metasomatized by a $0.1 \%$ MORB-source melt. However, some $\mathrm{Pb}$ isotope heterogeneity is required in the end-members, and/or the $\mathrm{Pb}$ isotope variation reflects variable radiogenic ingrowth since the metasomatic event, which must have occurred within the last few hundred million years.

\section{Acknowledgments}

The analytical work was funded by NSF grant EAR-9418168. Sheth was supported by a SOEST 
Young Investigator award at the University of Hawaii. We thank Denys VonderHaar for valuable assistance in the ICP-MS lab, and Bill White for use of his unpublished data for Réunion.

\section{REFERENCES}

Albarède, F., and Tamagnan, V., 1988, Modelling the recent geochemical evolution of the Piton de la Fournaise volcano, Réunion Island: Journal of Petrology, v. 29, p. 997-1030.

Albarède, F., Luais, B., Fitton, J. G., Semet, M., Kaminski, E., Upton, B. G. J., Bachèlery, P., and Cheminée, J.-L., 1997, The geochemical regimes of Piton de la Fournaise volcano (Réunion) during the last 530,000 years: Journal of Petrology, v. 38, p. 171-201.

Anderson, D. L., 1995, Lithosphere, asthenosphere, and perisphere: Reviews of Geophysics, v. 33, p. 125-149. , 1996, Enriched asthenosphere and depleted plumes: International Geology Review, v. 38, p. 1-21.

Arth, J. G., 1976, Behavior of trace elements during magmatic processes-a summary of theoretical models and their applications: Journal of Research of the United States Geological Survey, v. 4, p. 41-47.

Bachèlery, P., Blum, P. A., Cheminée, J. L., Chevallier, L., Gaulon, R., Girardin, N., Jaupart, C., Lalanne, F., Le Mouel, J. L., Ruegg, J. C., and Vincent, P., 1982, Eruption at Le Piton de la Fournaise Volcano on 3 February 1981: Nature, v. 297, p. 395-397.

Baxter, A. N., 1972, Magmatic evolution of Mauritius, western Indian Ocean: Unpubl. Ph.D. dissertation, University of Edinburgh, 177 pp.

, 1975a, Petrology of the Older Series lavas from Mauritius, Indian Ocean: Geological Society of America Bulletin, v. 86, p. 1449-1458.

, 1975b, K/Rb ratios in some volcanic rocks from Mauritius, Indian Ocean: Geochimica et Cosmochimica Acta, v. 39, p. 1573-1576.

, 1976, Geochemistry and petrogenesis of primitive alkali basalt from Mauritius, Indian Ocean: Geological Society of America Bulletin, v. 87, p. 10281034.

Baxter, A. N., Upton, B. G. J., and White, W. M., 1985, Petrology and geochemistry of Rodrigues Island, Indian Ocean: Contributions to Mineralogy and Petrology, v. 89, p. 90-101.

Campbell, I. H., and Griffiths, R. W., 1990, Implications of mantle plume structure for the evolution of flood basalts: Earth and Planetary Science Letters, v. 99, p. 79-93.

Chen, C.-Y., and Frey, F. A., 1983, Origin of Hawaiian tholeiite and alkalic basalt: Nature, v. 302, p. 785789.

, 1985, Trace element and isotopic geochemistry of lavas from Haleakala volcano, East Maui, Hawaii:
Implications for the origin of Hawaiian lavas: Journal of Geophysical Research, v. 90, p. 8743-8768.

Clague, D. A., 1987, Hawaiian alkaline volcanism, in Fitton, J. G., and Upton, B. G. J., eds., Alkaline igneous rocks: Geological Society of London, Special Publications, v. 30, p. 227-252.

Clague, D. A., and Dalrymple, G. B., 1988, Age and petrology of alkalic postshield and rejuvenated-stage lava from Kauai, Hawaii: Contributions to Mineralogy and Petrology, v. 99, p. 202-218.

Clague, D. A., and Frey, F. A., 1982, Petrology and trace element geochemistry of the Honolulu volcanics, Oahu: Implications for the oceanic mantle below Hawaii: Journal of Petrology, v. 23, p. 447-504.

Class, C., and Goldstein, S. L., 1997, Plume-lithosphere interactions in the ocean basins: Constraints from source mineralogy: Earth and Planetary Science Letters, v. 150, p. 145-260.

Class, C., Goldstein, S. L., Altherr, R., and Bachèlery, P., 1998, The process of plume-lithosphere interactions in the ocean basins - the case of Grande Comore: Journal of Petrology, v. 39, p. 881-903.

Duncan, R. A., 1990, The volcanic record of the Réunion hotspot, in Duncan, R. A., Backman, J., Peterson, L. C., et al., eds., Proceedings of the Ocean Drilling Program, Scientific Results, v. 115, p. 3-10.

Duncan, R. A., and Hargraves, R. B., $1990,{ }^{40} \mathrm{Ar} /{ }^{39} \mathrm{Ar}$ geochronology of basement rocks from the Mascarene Plateau, the Chagos Bank, and the Maldives Ridge, in Proceedings of the Ocean Drilling Program, Scientific Results, v. 115, p. 43-51.

Feigenson, M. D., 1984, Geochemistry of Kauai volcanics and a mixing model for the origin of Hawaiian alkalic basalts: Contributions to Mineralogy and Petrology, v. 87, p. 109-119.

Fisher, R. L., Johnson, G. L., and Heezen, B. C., 1967, Mascarene Plateau, western Indian Ocean: Geological Society of America Bulletin, v. 78, p. 1247-1266.

Fisher, R. L., Sclater, J. G., and McKenzie, D. P., 1971, Evolution of the Central Indian Ridge, Western Indian Ocean: Geological Society of America Bulletin, v. 82, p. 553-562.

Fisk, M. R., Upton, B. G. J., and Ford, C. E., 1988, Geochemical and experimental study of the genesis of magmas of Réunion Island, Indian Ocean: Journal of Geophysical Research, v. 93, p. 4933-4950.

Francis, D., and Ludden, J., 1995, The signature of amphibole in mafic alkaline lavas: A study in the Northern Canadian Cordillera: Journal of Petrology, v. 36, p. 1171-1191.

Frey, F. A., Clague, D., Mahoney, J. J., and Sinton, J. M., 2000, Volcanism at the edge of the Hawaiian plume: Petrogenesis of submarine alkalic lavas from the North Arch volcanic field: Journal of Petrology, v. 41, p. 667691.

Frey, F. A., Weis, D., Borisova, A. Yu., and Xu, G., 2002, Involvement of continental crust in the formation of the 
Cretaceous Kerguelen plateau: New perspectives from ODP Leg 120 sites: Journal of Petrology, v. 43, p. 1207-1239.

Galer, S. J. G., 1999, Optimal double and triple spiking for high precision lead isotopic measurement: Chemical Geology, v. 157, p. 255-274.

Gillot, P.-Y., and Nativel, P., 1989, Eruptive history of the Piton de la Fournaise volcano, Réunion Island, Indian Ocean: Journal of Volcanology and Geothermal Research, v. 36, p. 53-65.

Govindaraju, K., 1989, Compilation of working values and sample descriptions for 272 geostandards: Geostandards Newsletter, v. 13, p. 1-113.

Hanan, B. B., and Graham, D. W., 1996, Lead and helium isotope evidence from oceanic basalts for a common deep source of mantle plumes: Science, v. 272, p. 991995.

Hanyu, T., Dunai, T. J., Davies, G. R., Kaneoka, I., Nohda, S., and Uto, K., 2001, Noble gas study of the Réunion hotspot: Evidence for distinct less-degassed mantle sources: Earth and Planetary Science Letters, v. 193, p. 83-98.

Hirose, K., 1997, Partial melt compositions of carbonated peridotite at $3 \mathrm{Gpa}$ and role of $\mathrm{CO}_{2}$ in alkali-basalt magma generation: Geophysical Research Letters, v. 24, p. 2837-2840.

Irvine, T. N., and Baragar, W. R. A., 1971, A guide to the chemical classification of the common volcanic rocks: Canadian Journal of Earth Sciences, v. 8, p. 523-548.

Ito, E., White, W. M., and Göpel, C., 1987, The O, Sr, Nd, and $\mathrm{Pb}$ isotope geochemistry of MORB: Chemical Geology, v. 62, p. 157-176.

Jain, J. C., and Neal, C. R., 1996, Report of the ICP-MS facility, 1993-1996: South Bend, IN: Notre Dame University, Open File Report, $30 \mathrm{p}$.

Le Bas, M. J., Le Maitre, R. W., Streckeisen, A., and Zanettin, B., 1986, A chemical classification of volcanic rocks on the total alkali-silica diagram: Journal of Petrology, v. 27, p. 745-750.

Maaløe, S., James, D., Smedley, P., Petersen, S., and Garmann, L. B., 1992, The Koloa Volcanic suite of Kauai, Hawaii: Journal of Petrology, v. 33, p. 761-784.

Macdonald, G. A., 1968, Composition and origin of Hawaiian lavas, in Coats, R. E., Hay, R. L., and Anderson, C. A., eds., Studies in volcanology: Geological Society of America Memoirs, v. 116, p. 477-522.

Macdonald, G. A., and Katsura, T., 1964, Chemical composition of Hawaiian lavas: Journal of Petrology, v. 5, p. 82-133.

Mahoney, J. J., Duncan, R. A., Khan, W., Gnos, E., and McCormick, G. R., 2002, Cretaceous volcanic rocks of the South Tethyan suture zone, Pakistan: Implications for the Réunion hotspot and the Deccan traps: Earth and Planetary Science Letters, v. 203, p. 295-310.

Mahoney, J. J., Natland, J. H., White, W. M., Poreda, R., Bloomer, S. H., Fisher, R. L., and Baxter, A. N., 1989,
Isotopic and geochemical provinces of the western Indian ocean spreading centers: Journal of Geophysical Research, v. 94, p. 4033-4052.

Mahoney, J. J., Nicollet, C., and Dupuy, C., 1991, Madagascar basalts: Tracking oceanic and continental sources: Earth and Planetary Science Letters, v. 104, p. $350-363$.

McDougall, I., 1971, The geochronology and evolution of the young oceanic island of Réunion, Indian Ocean: Geochimica et Cosmochimica Acta, v. 35, 261-270.

McDougall, I., and Chamalaun, F. G., 1969, Isotopic dating and geomagnetic polarity studies on volcanic rocks from Mauritius, Indian Ocean: Geological Society of America Bulletin, v. 80, p. 1419-1442.

McDougall, I., Upton, B. G. J., and Wadsworth, W. J., 1965, A geological reconnaissance of Rodrigues Island, Indian Ocean: Nature, v. 206, p. 26-27.

Morgan, W. J., 1981, Hotspot tracks and the opening of the Atlantic and Indian Oceans, in Emiliani, C., ed., The Sea: New York, NY, John Wiley, v. 7, p. 443-487.

O'Hara, M. J., Richardson, S. W., and Wilson, G., 1971, Garnet-peridotite stability and occurrence in the crust and mantle: Contributions to Mineralogy and Petrology, v. 32, p. 48-68.

Peng, Z. X., and Mahoney, J. J., 1995, Drillhole lavas from the northwestern Deccan Traps, and the evolution of Réunion hotspot mantle: Earth and Planetary Science Letters, v. 134, p. 169-185.

Potts, P. J., Tindle, A. G., and Webb, P. C., 1992, Geochemical reference material compositions: Rocks, minerals, sediments, soils, carbonates, refractories and ores used in research and industry: Caithness, UK, Whittles Publishing.

Reiners, P. W., and Nelson, B. K., 1998, Temporal-compositional-isotopic trends in rejuvenated stage magmas of Kauai, Hawaii, and implications for mantle melting process: Geochimica et Cosmochimica Acta, v. 62, p. 2347-2368.

Richards, M. A., Duncan, R. A., and Courtillot, V. E., 1989, Flood basalts and hotspot tracks: Plume heads and tails: Science, v. 246, p. 103-107.

Roden, M. F., Frey, F. A., and Clague, D. A., 1984, Geochemistry of tholeiitic and alkalic lavas from the Koolau Range, Oahu, Hawaii: Implications for Hawaiian volcanism: Earth and Planetary Science Letters, v. 69, p. 141-158.

Smith, A. D., 1993, The continental mantle as a source for hotspot volcanism: Terra Nova, v. 5, p. 452-460.

Smith, A. D., and Lewis, C., 1999, The planet beyond the plume hypothesis: Earth-Science Reviews, v. 42, p. 135-182.

Späth, A., le Roex, A. P., and Duncan, R. A., 1996, The geochemistry of lavas from the Comores Archipelago, western Indian Ocean: petrogenesis and mantle source region characteristics: Journal of Petrology, v. 37, p. 961-991. 
Staudacher, T., Sarda, P., and Allègre, C. J., 1990, Noble gas systematics of Réunion Island, Indian Ocean: Chemical Geology, v. 89, p. 1-17.

Stearns, H. T., 1940, Four-phase volcanism in Hawaii: Geological Society of America Bulletin, v. 51, p. 1947-1948.

Stille, P., Unruh, D. M., and Tatsumoto, M., 1983, Pb, Sr, $\mathrm{Nd}$, and $\mathrm{Hf}$ isotopic evidence of multiple sources for Oahu, Hawaii basalts: Nature, v. 304, p. 25-29.

Sun, S.-s., and McDonough, W. F., 1989, Chemical and isotopic systematics of oceanic basalts: Implications for mantle composition and processes, in Saunders, A. D., and Norry, M. J., eds., Magmatism in the ocean basins: Geological Society of London, Special Publications, v. 42, p. 313-345.

Verma, S. P., Torres-Alvarado, I. S., and Sotelo-Rodríguez, Z., 2002, SINCLAS: Standard igneous norm and volcanic rock classification system: Computers and Geosciences, v. 28, p. 711-715.

White, W. M., Cheatham, M. M., and Duncan, R. A., 1990, Isotope geochemistry of Leg 115 basalts and inferences on the history of the Réunion mantle plume, in Duncan, R. A., Backman, J., Peterson, L. C., et al., eds., Proceedings of the Ocean Drilling Program, Scientific Results, v. 115, p. 53-61. 